\title{
Policy Uncertainty and Loan Loss Provisions \\ in the Banking Industry
}

\begin{abstract}
Policy uncertainty is an increasingly important issue facing many economies. In this paper, we examine how banks accrue for loan losses in response to policy uncertainty (PU) and the implications of these accruals in terms of actual loan losses and future liquidity creation. Consistent with banks recognizing more loan losses in anticipation of PU's depressive effects, we document a contemporaneous positive association between PU and loan loss accruals. This positive association is more pronounced for banks with a riskier loan portfolio and that have a history of lower loan loss reserves. We also find that banks making more loan loss provisions in times of higher PU have significantly higher future loan charge-offs and lower future liquidity creation. Overall, our paper highlights that PU affects the loan loss accruals of banks and that these accruals reflect rational expectations about PU's depressive effects on the economy.
\end{abstract}

JEL classifications: G21; M41; G32

Keywords: Policy uncertainty; Accrual estimates; Banking; Loan loss provisions 


\section{Introduction}

A nascent and growing literature examines the implications of policy uncertainty (PU). PU refers to uncertainty regarding fiscal, monetary or regulatory policy. Specifically, the uncertainty derives from whether existing policy will change in the future or what impact a newly introduced policy will have on the private sector. PU has risen significantly in the United States for two reasons: i) growth in government spending, taxes and regulation and ii) increased political polarization and its impact on the policy-making process and policy choices (Baker et al., 2014). Recent research documents that PU impacts the real economy and corporate decisions (e.g., Bloom et al., 2012; Baker and Bloom, 2013; Baker, Bloom and Davis, 2016).

In this paper, we extend the literature by examining whether PU is associated with banks’ accrual estimates, specifically, with their loan loss provisions. In the banking industry, loan loss provisions are the most significant and economically important proportion of total accruals (Beatty and Liao, 2014). Understanding how banks accrue loan losses in times of PU is important because banks play a vital role in supplying credit to the economy and accrued losses can affect regulatory capital and credit provision (e.g., Kashyap and Stein, 2000; Jiménez et al., 2012; Beatty and Liao, 2014). However, as we discuss in detail in Section 2, there is ex-ante tension in the hypothesis on whether banks make higher or lower loan loss provisions in the face of higher PU.

Recent research documents that policy uncertainty has depressive effects on the real economy, e.g., lower GDP growth (Bloom et al., 2012; Baker and Bloom, 2013), lower corporate investment and employment (Bhagat and Obreja, 2013; Baker, Bloom and Davis, 2016; Gulen and Ion, 2016) and lower production and productivity for firms (Bloom, 2009; Bachmann, 
Elstener and Sims, 2013). ${ }^{1}$ These effects are likely to affect a bank's borrowers' ability to repay their loans. The nature of loan loss provisioning suggests that the amount of loan loss provisions provides a useful indication of bank managers’ private information about anticipated loan losses. Hence, managers can use loan loss provisions to reveal private information and properly manage investors' expectations. Scholes et al. (1990), for example, demonstrate that bank managers can lower their cost of capital by exercising discretion over loan loss provisions to convey their private information to investors. In addition, higher loan loss provisions in higher PU periods can also demonstrate a willingness to be more proactive in loan loss recognition, which in turn can improve the bank’s long-term prospects (Beatty and Liao, 2014). Hence, one might expect banks to make higher loan loss provisions in times of higher PU.

Despite this expectation, adverse macroeconomic conditions can create incentives to hide bad news. ${ }^{2}$ Prior research has shown that banks can hide bad news (e.g., weak earnings and low regulatory capital) by reducing loan loss provisions (see the survey by Beatty and Liao, 2014). To the extent that higher PU generates more difficult economic conditions (e.g., less demand for loans, more loan losses, greater scarcity of capital and downward pressure on regulatory capital), banks are likely to face more competition and survival concerns. These adverse conditions typically create incentives (e.g., career concerns) to hide bad news (Kothari, Shu and Wysocki, 2009). Specifically, in the context of banks, one might expect a bank to opportunistically lower loan loss provisions to report higher earnings and regulatory capital, possibly to avoid perceptions that the bank is weak, losing borrowers and depositors and attracting regulatory

\footnotetext{
${ }^{1}$ The Federal Open Market Committee (2009) and the International Monetary Fund (IMF) (2012, 2013) also suggest that uncertainty about US and European economic policies contributed to the steep depression in 2008-2009 and the slow recovery afterward.

${ }^{2}$ Many prior studies either argue or provide evidence that managers can have incentives (e.g., career concerns) to withhold or delay the disclosure of bad news (e.g., Graham, Harvey and Rajgopal, 2005; Kothari et al., 2009).
} 
scrutiny. A large body of banking literature provides evidence on the opportunistic use of loan loss provisions (Beatty and Liao, 2014). Furthermore, the uncertainty itself might give banks more room to engage in reporting bias (Fischer and Verrecchia, 2000). Hence, one might expect banks to report lower loan loss provisions in times of higher PU.

To study the link between PU and loan loss provisions, we construct a comprehensive sample of the US commercial banks identified in call reports. To measure PU, we rely on the PU index introduced in Baker, Bloom and Davis (BBD) (2016). This index consists of four components. The first and most important component captures PU using a newspaper-based approach, based on the frequency of articles in 10 leading US newspapers that contain the following trio of terms: “economic” or “economy”; “uncertain” or "uncertainty”; and one or more of "'Congress”, “deficit”, “Federal Reserve”, “legislation”, “regulation” or "'White House". The other three components capture tax code expirations, disagreement over CPI forecasts and disagreement over government purchases forecasts. Many recent studies have used this index to examine the economic consequences of PU (e.g., Bhagat and Obreja, 2013; Brogaard and Detzel, 2015; Gulen and Ion, 2016; Kim and Kung, 2017; Nguyen and Phan, 2017). We first examine the association between PU and loan loss provisions. If bank managers perceive the policy uncertainty and take into account its expected depressive effects, then after controlling for other determinants, variation in loan loss provisions should be positively associated with PU. If bank managers engage in upwards capital and earnings management when facing problems induced by higher PU, then we would observe a negative relation between PU and loan loss provisions. Using quarterly data from 1996 to 2016, we find a positive relation between PU and loan loss provisions, i.e., the higher the PU is in a specific quarter, ceteris paribus, the higher the loan loss provisions will be in the quarter. The effects are statistically and 
economically significant: on average, when PU is higher by one standard deviation, loan loss provisions are higher by $11.42 \%$ of the mean value during our sample period. Therefore, the main results support the view that bank managers consider PU's depressive effects and use loan loss provisions to signal the loan conditions.

We conduct a series of cross-sectional tests to explore the heterogeneous effects of PU on loan loss provisions. These tests are designed to examine our argument that the key channel through which higher PU leads to more accrued loan losses is bank managers' expectation of future economic depressive effects that would adversely affect borrowers. First, to the extent that depressive effects indeed drive the relationship, we expect the positive association between loan loss provisions and PU to be greater when the banks are riskier because, to such banks, losses are expected to be greater when there is a deterioration of economic conditions. As noted earlier, prior studies document higher PU to be a harbinger of deteriorating economic conditions. We find that the positive association between PU and loan loss provisions is more pronounced for banks with a higher proportion of nonperforming loans, those with a lower level of loan type diversification and those with a lower level of capital adequacy at the beginning of the quarter in which we measure PU and loan loss provisions.

Next, we examine whether banks that have previously accrued more loan loss reserves are more insulated from having to record additional amounts of loan loss provisions when PU is higher. Beatty and Liao (2011) find that banks that have been more timely in recording loan losses in the past are less adversely affected, in terms of their lending, during recessionary periods. In the same spirit, we expect that these banks, because they have already been more proactive in accruing expected loan losses, will have less need to record even more expected loan losses with the arrival of high PU. Consistent with this expectation, we find that for banks that 
have historically larger loan loss reserves as a proportion of total nonperforming loans or as a multiple of net charge-offs, there is a less pronounced positive association between PU and loan loss provisions. Collectively, the evidence from these two cross-sectional tests indicates that loan loss provisions' sensitivity to PU is significantly higher for banks that are more exposed to it, which is consistent with the view that with respect to PU, loan loss provisioning reflects bank managers’ expectations about future loan losses.

In addition to economic expectations, two other explanations for high loan loss provisions in times of higher PU are i) managers' attempts to opportunistically shift earnings from uncertain to more certain times (Stein and Wang, 2016) and ii) negative managerial sentiment not supported by underlying loan conditions (Hribar et al., 2017). To provide evidence that making more loan loss provisions during higher PU periods indeed reflects the economic expectations about future loan losses, we further examine the association between PU and borrowers' future defaults and how it varies with the current quarter's loan loss provisions. Because the depressive effect of PU is expected to lead to more borrowers defaulting in the future (e.g., Baker et al., 2016), economic expectations should foresee a positive relation between PU and future defaults. In addition, to the extent that more loan loss provisions in times of higher PU reflect economic expectations about future loan losses, we predict a stronger positive relation between PU and future defaults for banks that make more loan loss provisions. Using loan charge-offs to measure actual defaults, we find that PU is positively associated with loan charge-offs in the next quarter as well as with the accumulated charge-offs in the next four quarters, corroborating its depressive effects. More importantly, we find that the positive relation between PU and future charge-offs is significantly stronger for banks that accrue more losses in the current quarter, corroborating banks' economic expectations. In an additional analysis of the 
economic expectations conjecture, we also examine whether future liquidity creation is cut more significantly for banks that make more loan loss provisions in times of high PU. We find results consistent with our conjecture.

Our study makes two contributions to the literature. First, as noted earlier, recent literature has viewed PU as an increasingly common macroeconomic phenomenon, with important implications for the economy, firms and individuals (Baker et al., 2014). While earlier studies on PU focus more on its economic implications, more recent research examines corporate decisions. For example, Baker, Bloom and Davis (2016) and Kim and Kung (2017) find that firms reduce investment under a higher level of uncertainty. Nguyen and Phan (2017) find that policy uncertainty is negatively related to firm acquisitiveness and positively related to the time it takes to complete M\&A deals. Our paper complements and contrasts with the recent research on the information-related outcomes of PU. For example, Nagar, Schoenfeld and Wellman (2017) find that PU exacerbates information asymmetry among investors and increases voluntary disclosure. To the best of our knowledge, our paper is the first to examine how PU impacts banks' reporting of their expected loan losses and how such reporting is related to the riskiness of its existing loan portfolio and the extent of past loan loss reserves. We also demonstrate that such banks' anticipation of greater loan losses in times of higher PU materializes into future actual loan losses. Our findings suggest that at least some banks are following regulatory guidance in that their loan loss provisions take into account broader macroeconomic, and not simply historical loan-related, indicators.

Second, our paper contributes to the banking literature by linking liquidity creation to bank accounting and PU. Liquidity creation is undoubtedly an important role of the banking system (Berger and Bouwman, 2009). Prior studies have examined various factors that could 
affect liquidity creation (e.g., Levine and Zervos, 1998; Beatty and Liao, 2011). Beatty and Liao (2011) is a closely related study that finds that reductions in lending during recessionary periods are smaller when banks have previously been more timely in recognizing loan losses. In contrast to and complementing Beatty and Liao (2011), we focus on anticipation of loan losses in times of PU and how such anticipation affects liquidity creation. First, we show that liquidity creation is negatively affected by higher PU after controlling for many other contemporaneous economic factors and that this finding is consistent with higher PU being a harbinger for more difficult times ahead. More importantly, we show that when banks anticipate higher loan losses, as reflected in higher loan loss provisions, they cut back even more on liquidity creation when there is higher PU. One implication of this finding is that the depressive effects of PU the prior literature documents (e.g., reduction in investment and employment) could be at least partly driven by banks' cutting back on liquidity creation in anticipation of loan losses.

The remainder of the paper is organized as follows. We begin by reviewing the relevant literature and introducing the background for our research, followed by our hypotheses development. Then we introduce the data and sample and design for the empirical tests, as well as discuss the results. Finally, the last section concludes.

\section{Background and hypotheses development}

Politicians and regulatory institutions frequently make decisions that alter the environment in which firms operate and companies routinely face a significant amount of uncertainty about the timing, content and potential impact of fiscal, regulatory and monetary policy decisions, which is referred to as policy uncertainty (PU) (Gulen and Ion, 2016). Due to growth in government spending, taxes and regulation and the increased political polarization induced by rising voter and media polarization and income inequality, PU in the US has 
experienced a secular rise since the 1960s (Baker et al., 2014). The significantly increasing trend can be seen in the newspaper-based PU index, introduced in Baker, Bloom and Davis (2016), which corresponds to a dramatic rise in the frequency of discussion of policy uncertainty in the Federal Reserve’s Beige Book, released starting from the 1980s.

The banking industry is sensitive to economic policies, including the uncertainty underlying them, because these policies could affect ability and willingness of banks to lend and borrowers to repay their loans. ${ }^{3}$ To improve the accuracy of loan loss estimation, the SEC and bank regulators recommend that bank managers take a series of macro factors into consideration, including economic growth and the business cycle. For example, the FFIEC (1993) stated that “Although historical loss experience provides a reasonable starting point for the institution's analysis, historical losses, or even recent trends in losses are not, by themselves, a sufficient basis to determine the appropriate level for the ALLL [allowance for loan and lease losses]. Management should also consider any factors..., including but not limited to...changes in national and local economic and business conditions....” The SEC Staff Accounting Bulletin (Release No. SAB 102) similarly recommends that registrants should consider the impact of current environmental factors when estimating loan losses (SEC, 2001).

In principle, loan loss provisions are made to communicate the underlying condition of a bank's loan portfolios to stakeholders (AICPA, 1983). The depressive effect of policy uncertainty on the real economy is well-documented anecdotally and in recent empirical studies. Early theoretical work such as that by Bernanke (1983) demonstrates that uncertainty in general creates incentives for firms to delay investment and hiring by temporarily increasing the rewards of waiting for more information. Such predictions are in keeping with anecdotes about PU's

\footnotetext{
${ }^{3}$ For example, using Chinese commercial banks as a sample, Chi and $\mathrm{Li}$ (2017) document a positive relation between policy uncertainty and banks' credit risks.
} 
depressive effects that appear in the popular press. For example, on May 16, 2017, Reuters quoted Chris Griffith, CEO of Angle American Platinum, as saying, "Uncertainty is dreadful for investment. It puts pressure on jobs and some mines that are already loss-making ... there will be further rationalization of the mines and it's going to lead to further job losses ...". ${ }^{4}$ Using a newly developed measure of PU, Baker, Bloom and Davis (2016) provide empirical evidence at the macro and firm levels that policy uncertainty has a negative impact on investment and employment. Given that uncertainty reduces GDP growth (Bloom et al., 2012; Baker and Bloom, 2013), firm production (Bachmann, Elstener and Sims, 2013) and productivity (Bloom, 2009), firms are more likely to default when PU is higher. The high unemployment rate resulting from high PU can also increase uncertainty for household income. Similarly, recent research in corporate finance also highlights the depressive effect of policy uncertainty. For example, Bonaime et al. (2018) find that policy uncertainty is strongly negatively associated with M\&A activity at the macro and firm levels. Gulen and Ion (2016) report that policy uncertainty constrains capital expenditures and Starks and Sun (2016) find that it affects mutual funds' investment decisions.

To the extent that banks expect the depressive effects of PU on their borrowers to result in more future loan losses, banks should accrue more loan loss provisions when PU is high. Moreover, prior literature suggests that higher loan loss provisions can signal banks' financial strength and that being more proactive in recognizing loan losses can have positive consequences such as enabling banks to better weather capital crunches and reducing excessive risk-taking (Beatty and Liao, 2014). For example, Beaver et al. (1989) find that higher loan loss allowances are associated with higher market values, consistent with markets perceiving a bank's earnings

\footnotetext{
${ }^{4}$ The news article can be found online: http://www.reuters.com/article/us-platinum-week-anglo-platinum/moresouth-african-mining-jobs-at-stake-on-policy-uncertainty-amplats-ceo-idUSKCN18C1YA.
} 
power to be strong enough to withstand a "hit to earnings" from a higher level of loan loss provisions. Hence, from the perspective of accounting for the depressive effects of PU, one might expect greater loan loss provisions in higher PU periods.

However, while one might believe that accruals should be based on economic expectations, researchers in accounting and finance have recognized for years that banks also use latitude in accounting rules to opportunistically manage loan loss provisions, especially when there are incentives to do so (see survey by Beatty and Liao, 2014). We argue the macroeconomic conditions can give rise to incentives to manipulate loan loss provisions, especially when loan loss provisions directly affect earnings and regulatory capital, two important indicators of the safe and soundness of banks. ${ }^{5}$ In particular, to the extent that higher PU generates more difficult economic conditions (e.g., less demand for loans, more loan losses, greater scarcity of capital and downward pressure on regulatory capital), we expect banks to face more competition, regulatory scrutiny for safe and soundness and even survival concerns. Perhaps not surprisingly, banks, and firms more generally, typically have incentives to hide bad news in the face of such adverse conditions (e.g., Healy and Wahlen, 1999; Beatty, Ke and Petroni, 2002; Cohen et al., 2014). Anecdotal evidence also supports this argument. For example, the recent financial crisis provoked significant public concern and consensus that loan loss provisions and allowances prior to the crisis were inadequate to cover the credit losses incurred by banks (Financial Accounting Standards Board [FASB], 2012).

Two pieces of evidence from prior literature support the view that adverse economic conditions can lead to an opportunistic reduction in loan loss provisions. First, prior studies document a negative association between loan loss provisions and capital ratios, suggesting that

\footnotetext{
${ }^{5}$ For example, in evaluating the safe and soundness of an institution, bank regulators follow the CAMELS system: Capital adequacy, Asset quality, Management, Earnings, Liquidity and Sensitivity (to systemic risk).
} 
banks use loan loss provisions to reduce the expected regulatory costs associated with violating capital requirements (Moyer, 1990; Beatty et al., 1995; Ahmed, Takeda and Thomas, 1999). Second, prior literature finds a positive association between loan loss provisions and earnings before loan loss provisions, suggesting that banks discretionarily manage earnings upwards (downwards) when true earnings are low (high) (e.g., Collins et al., 1995; Beatty et al., 2002).

In addition, theory suggests that uncertainty may make it easier for managers to conceal reporting bias (Dye, 1988; Jung and Kwon 1988; Fischer and Verrecchia, 2000). For example, banks can claim that policy uncertainty makes it harder to determine whether loan losses are probable. This, in turn, justifies a delay in the recognition of loan losses until there is greater certainty about a policy and its implications. Hence, to the extent that higher PU creates incentives for banks to manage earnings and/or regulatory capital upwards to hide bad news, one might expect banks to record lower loan loss provisions during such periods. ${ }^{6}$

In short, the arguments and evidence in the prior literature suggest that there could be a positive or negative association between PU and loan loss provisions. Nevertheless, we predict that on balance, banks tend to record more loan loss provisions during higher PU periods. A key reason is that PU is a macroeconomic effect observable by various stakeholders, including auditors and investors, and thus could constrain opportunism in reporting loan loss provisions. Specifically, to the extent that higher PU results in stakeholders expecting more difficult times ahead, it would be harder for banks to justify lower loan loss provisions at such times. Hence, our first hypothesis, stated in alternative form, is:

H1. Banks make more loan loss provisions in times of higher PU.

\footnotetext{
${ }^{6}$ We might also find no relation between loan loss provisions and PU because the accounting standards do not explicitly require banks to record higher loan loss provisions when there is higher uncertainty, whether it be economic policy uncertainty or another type. In fact, standard setters have made a recent push towards more forward-looking provisioning for losses, as evidenced by the introduction of a new accounting standard, FASB ASU No. 2016-13, which will be mandatory for the fiscal year beginning after Dec. 15, 2019.
} 
Taking into account banks' key operating characteristics, we next derive several auxiliary hypotheses to shed light on the channel through which policy uncertainty affects loan loss provisions. As we argue above, PU could adversely affect borrowers’ prospects, thus increasing bank managers' expectation of future loan defaults. Banks with more risky portfolios typically expose themselves to more loan losses when economic conditions worsen. For example, during the recent financial crisis, higher risk exposure in loan portfolios was associated with a poorer performance and a higher probability of insolvency and bank failure (Campbell, 2007; Knaup and Wagner, 2012; Ng and Roychowdhury, 2014). In other words, given that banks' loan portfolio risk reflects the extent of their vulnerability to borrowers' defaults, when PU rises, the magnitude of the incremental credit losses a bank will suffer depends on its loan portfolio risk. Hence, banks with higher risk should expect more incremental loan losses and make even more loan loss provisions when PU is higher. Accordingly, we state this hypothesis as follows:

H2. The association between loan loss provisions and PU will be greater for riskier banks.

Banks with more timely loan loss recognition should be better prepared for economic shocks. In practice, loan loss provisions for a specific accounting period are typically not directly estimated and two steps are usually taken to arrive at an estimated number. In the first, bank managers estimate the total losses for all outstanding loans at each period end and present this number as the loan loss allowance in the balance sheet. Then current-period loan loss provisions are calculated as the increase in the allowance compared to the prior period end and adjusted by net write-offs. Thus, the estimated amount of loan loss provisions depends on how much of the total credit losses have been accrued into the allowance in previous periods. In general, banks will accrue less loan loss into the pool of allowance if they have already accrued more loan losses in previous periods. Hence, when PU increases, the increase in loan loss allowance, which 
will be recognized as current-period loan loss provisions, should be smaller for banks that have already accrued a greater allowance in previous periods. We state this hypothesis as follows:

H3. The association between loan loss provisions and PU will be lower for banks with more prior loan loss reserves.

To further substantiate our economic-based explanation for the relation between PU and loan loss provisions, in the following hypothesis we shift our focus from loan loss expectation to realization. Based on our earlier discussion, we posit that, on balance, the contemporaneous relation between PU and loan loss provisions is positive because bank managers expect more future loan defaults when PU is high given its expected depressive effects on the real economy at both the macro and micro levels (e.g., Bloom, 2009; Bloom et al., 2012; Baker and Bloom, 2013; Bachmann, Elstener and Sims, 2013; Baker, Bloom and Davis, 2016). In terms of the actual realization of loan outcomes (as opposed to the accruals related to the expectation of loan outcomes), higher PU is expected to lead to more future loan defaults and thus more loan chargeoffs by banks. Figure 1 depicts the relationship between loan loss provisions, loan loss allowance and loan charge-offs. By definition, loan loss provisions reflect managers' estimation of future loan loss realization, which will be recorded as loan charge-offs when the loan actually becomes uncollectible.

Given the link between loan loss provisions and charge-offs, if managers rationally take into account the economic consequences of PU and use loan loss provisions as a signal of expected loan conditions (e.g., Scholes et al., 1990; Wahlen, 1994; Beaver and Engel, 1996; Liu et al., 1997; Kanagaretnam et al., 2004, 2005), then we would expect more future charge-offs for banks that make more loan loss provisions in the current period. However, it is possible that the relation between PU and loan loss provision merely reflects bank managers' behavioral biases 
related to policy uncertainty. Under this alternative view, the sensitivity of loan loss provisions with respect to PU manifests from behavioral bias rather than from the future economic conditions that bank managers expect. For example, Hribar et al. (2017) find that managerial sentiment is negatively associated with loan loss provisions in the banking industry and that evidence from future loan charge-offs suggests that loan loss provisions result from the behavioral biases of under- (over-) provisioning in periods of high (low) managerial sentiment. In the case of behavioral bias as the explanation, one might anticipate that higher loan loss provisions in response to higher PU will be associated with smaller charge-offs in the future. However, since we predict that higher loan loss provisions in times of higher PU reflect the rational expectations of banks, we state this hypothesis as follows:

H4. The positive association between PU and future loan charge-offs will be greater for banks that make more loan loss provisions.

Banks play the important role of providing liquidity to the economy though their direct and indirect lending activities (Berger and Bouwman, 2009). Liquidity creation is a key function of banks, accomplished using deposits and other sources of capital to engage in lending, loan commitments and other off-balance-sheet guarantees. Bank liquidity creation has numerous positive economic effects, including delivering credit to informationally opaque borrowers without capital market opportunities (Levine and Zervos, 1998), providing depositors with liquid funds and payment services that are essential to a functioning economy (Kashyap, Rajan and Stein, 2002) and supplying loan commitments and derivatives like interest rate swaps that allow customers to plan their investments and hedge their financial risks (Boot, Greenbaum and Thakor, 1993). Bank liquidity creation has a stronger effect on economic growth than do other measures of bank output (Berger and Sedunov, 2017). Bank liquidity creation could also have a dark side 
for the economy - excessive bank liquidity creation is associated with an elevated probability of an impending financial crisis (Acharya and Naqvi, 2012; Berger and Bouwman, 2017).

To the extent that higher PU is a harbinger of deteriorating economic conditions, one would expect the equilibrium amount of liquidity creation in the economy to be lower due to a lower demand for and supply of credit. In other words, one would expect a negative association between PU and future liquidity creation. From the supply perspective, to the extent that current loan loss provisions reflect a bank's expectation of future economic conditions, one should expect a bank that makes greater loan loss provisions to cut back on credit supply even more because of its expectation of worse economic conditions. Another reason for this expectation is that loan loss provisions, while not affecting the amount of cash the bank has, reduce the amount of regulatory (tier 1 ) capital. ${ }^{7}$ A reduction in regulatory capital, in turn, can constrain the bank’s ability to lend. Hence, our final hypothesis is:

H5. The negative association between PU and future liquidity creation will be greater for banks that make more loan loss provisions.

\section{Sample, model, variables, and descriptive statistics}

\subsection{Sample}

Our sample includes all US commercial banks and the bank-level data are extracted from Call Reports filed with bank regulators. ${ }^{8}$ We obtain PU data from Baker, Bloom and Davis’ (2016) website. Since policy uncertainty is a macro-level variable with only time-series variation, we use quarterly instead of annual data to increase sample size and, by extension, the power of

\footnotetext{
${ }^{7}$ It is important to note that loan loss provisioning is essentially an accrual process. When a bank accrues for more anticipated losses, there is no direct impact on the amount of cash/capital the bank has.

${ }^{8}$ Data for all US commercial banks are publicly available online at the Federal Reserve Bank of Chicago: https://www.chicagofed.org/banking/financial-institution-reports/commercial-bank-data; we alternatively use the bank holding companies sample obtained from the Compustat Bank database and get empirical results that are qualitatively the same (untabulated).
} 
our tests. ${ }^{9}$ Other macro-level control variables are obtained from the Federal Reserve Bank of St. Louis and the US Bureau of Labor Statistics.

Even though by 1992 the US had fully implemented the Basel Capital Accord (BASEL), which introduced a new capital adequacy framework, the risk-based capital and risk-weighted assets required to calculate the risk-based capital ratio (an important control variable) have only been available in the Call Reports database since the first quarter of $1996 .{ }^{10}$ Therefore, our final sample consists of all bank-quarter observations with necessary data for constructing our model variables for the period from 1996:2 to 2016:4. ${ }^{11}$

\subsection{Model and variables}

Our first hypothesis, H1, suggests that on balance, the association between PU and loan loss provisions is positive mainly because PU's expected depressive effects on borrowers increase bank managers' assessment of future loan losses. To test this central hypothesis, we estimate the following pooled OLS equation:

$$
\begin{aligned}
& L L P_{i, t}=\beta_{0}+\beta_{1} P U \text { Index }_{t}+\beta_{2} \text { MacroUncertainty }_{t}+\beta_{3} \Delta N P L_{i, t-2}+\beta_{4} \Delta N P L_{i, t-1} \\
& +\beta_{5} \Delta N P L_{i, t}+\beta_{6} \Delta N P L_{i, t+1}+\beta_{7} S I Z E_{i, t-1}+\beta_{8} \Delta L O A N_{i, t}+\beta_{9} E B P_{i, t}+\beta_{10} C O_{i, t} \\
& +\beta_{11} C A P R 1_{i, t-1}+\beta_{12} A L W_{i, t-1}+\beta_{13} E_{A R N I N G V O L} L_{i, t-1} \\
& +\beta_{14} \text {HOMOGENEITY }_{i, t}+\beta_{15} \text { PUBLIC }_{i, t}+\beta_{16} \text { INTCONTROL }_{i, t} \\
& +\beta_{17} G D P G R W_{t}+\beta_{18} U N E M P G R W_{t}+\beta_{19} C_{S R E T}+\text { bank fixed effects } \\
& +\varepsilon
\end{aligned}
$$

\footnotetext{
${ }^{9}$ Since quarterly data are available for all US banks, most banking research uses bank-quarter observations, e.g., Beatty and Liao (2011), Bushman and Williams (2012, 2015) and Goetz et al. (2016).

${ }^{10}$ Alternatively, we follow Beck and Narayanamoorthy (2013) to start our sample period with 1992 (when BASEL took effect) and construct a capital ratio proxy as percentage of total equity to total assets. We get qualitatively similar results.

${ }^{11}$ The final sample period starts with the second quarter of 1996 because we have to control for the lagged riskbased capital ratio in our baseline model.
} 
where $L L P_{i, t}$ is the loan loss provision in quarter t scaled by the lagged total loans of bank $i$ and $P U$ Index $_{t}$ is the natural log of quarter t's overall PU index introduced in Baker, Bloom and Davis (2016). Our interest in Equation (1) centers on $\beta_{1}$. According to our central hypothesis, if policy uncertainty affects loan loss provisions, then when uncertainty is higher (lower), we expect the estimated provisions to be higher (lower) such that $\beta_{1}$ should be positive because the expected depressive effects of policy uncertainty increase bank managers' expectation of future loan losses.

Our interest is the effect of policy-related, rather than economy-wide, uncertainty. However, the BBD policy uncertainty index we use as our variable of interest is likely to be correlated with the general economic uncertainty. Hence, it is crucial for us to deal with economy-wide uncertainty as a possible omitted variable problem. Following Bonaime, Gulen and Ion (2018), we control for general macroeconomic uncertainty (MacroUncertainty $y_{t}$ ) in the model to avoid this problem. MacroUncertainty $t_{t}$ is defined as the principal component of the following four variables that capture macro-level economic uncertainty: (1) Jurado et al.'s (2015) uncertainty index, developed as the unforecastable component in a system of 279 macroeconomic variables; (2) the Chicago Board Options Exchange’s VXO index of implied volatility; (3) the cross-sectional standard deviation of cumulative returns during the quarter using the entire CRSP universe and (4) the cross-sectional standard deviation of year-on-year sales growth using the entire Compustat quarterly universe.

Following prior literature (e.g., Liu and Ryan, 2006; Beatty and Liao, 2011, 2014; Bushman and Williams, 2012; Hribar et al., 2017), we also control for a series of bank-level characteristics in the above baseline model. First, we include $\triangle N P L_{i, t-1}$ and $\triangle N P L_{i, t-2}$ because loan loss estimation is usually based on the historical trend of nonperforming loans, i.e., the 
accounting rule currently in effect for credit losses is backward looking. However, prior literature also suggests that to some extent, some banks are forward looking when making loan loss provisions. Therefore, we also include $\triangle N P L_{i, t}$ and $\triangle N P L_{i, t+1}$ in the model in case current and future quarter information about nonperforming loans is used in the estimation process. Secondly, because banks of different sizes typically face different levels of regulatory scrutiny and firm size is a common control in the accounting and finance literature, we control for lagged bank size $\left(S I Z E_{i, t-1}\right)$. We also control for loan growth rate $\left(\triangle L O A N_{i, t}\right)$ because credit risk will deteriorate if banks increase lending by extending credit to less financially healthy clients. Earnings before loan loss provisions $\left(E B P_{i, t}\right)$ and the lagged tier 1 risk-based capital ratio $\left(C A P R 1_{i, t-1}\right)$ are added to control for potential incentives for earning smoothing and/or capital management through loan loss provisions. We also control for net charge-offs $\left(\mathrm{CO}_{t}\right)$ and lagged loan loss allowance $\left(A L W_{i, t-1}\right)$ because of the inherent relationship between loan loss provisions, allowance and charge-offs. Specifically, banks could accrue a smaller provision during the current quarter if they have already recorded a sufficient allowance in previous quarters. Similarly, charge-offs will reduce the allowance level, thereby potentially affecting loan loss provisions. We scale those bank-level control variables by lagged total outstanding loans. In addition, we control for earnings volatility (EARNINGVOL $\left.L_{i, t-1}\right)$, the percentage of homogeneous loans (HOMOGENEITY ${ }_{i, t}$ ), bank listing status $\left(\right.$ PUBLIC $\left._{i, t}\right)$ and internal control requirements (INTCONTROL $L_{i, t}$ ) because they are potentially important determinants of loan loss provisions.

In addition to bank-level controls, we also control for several macro-level conditions, including GDP growth $\left(G D P G R W_{t}\right)$, unemployment rate growth $\left(U N E M P G R W_{t}\right)$ and the return on the S\&P/Case-Shiller US National Home Price Index $\left(C S R E T_{t}\right)$, because prior studies suggest that these factors can also influence loan loss provisions (e.g., Demirgüç-Kunt and Detragiache, 
1998; Demirgüç-Kunt et al., 2006; Louzis et al., 2012; Bushman and Williams, 2012; Beck and Narayanamoorthy, 2013). Moreover, these macro-level variables may also affect the level of policy uncertainty. We define the variables mentioned above in Appendix A and winsorize all continuous variables at the 1st and 99th percentiles. Finally, we include bank fixed effects to mitigate the omitted variable problem due to time-invariant factors. ${ }^{12}$ In the regression analysis, we always adjust standard errors for bank and quarter two-way clustering (Petersen, 2009; Gow, Ormazabal and Taylor, 2010).

\subsection{Descriptive statistics}

Table 1, Panel A reports summary statistics for the regression variables over the whole sample period. The full sample consists of 634,059 bank-quarter observations from 12,885 unique US commercial banks. We find that $L L P_{i, t}$ has a mean of 0.001 , suggesting that loan loss provisions are $0.1 \%$, on average, of lagged total loans. Since loan loss provisions are meant to estimate future charge-offs, we observe that the distributional statistics for charge-offs are very close to those for loan loss provisions. Panel B presents the Pearson correlations for these regression variables. The results show that loan loss provisions $\left(L L P_{i, t}\right)$ and the overall PU index $\left(P U\right.$ Index $\left._{t}\right)$ are positively correlated, consistent with our central hypothesis. We also find that $L L P_{i, t}$ is positively correlated with the changes in nonperforming loans $(\triangle N P L)$, net charge-offs $\left(C O_{i, t}\right)$, earnings volatility (EARNINGVOL $\left.L_{i, t-1}\right)$ and the internal control requirement $\left(\operatorname{INTCONTROL} L_{i, t}\right)$ while negatively correlated with lagged tier 1 capital ratio $\left(C A P R 1_{i, t-1}\right)$ and the proportion of homogeneous loans (HOMOGENEITY $\left.Y_{i, t}\right)$. In addition, as expected, the four macrolevel control variables, i.e., macroeconomic uncertainty (MarcroUncertaintyt), GDP growth

\footnotetext{
${ }^{12}$ Since the measure of PU is a macro-level variable with only time-series variation, the regression model cannot include quarter fixed effects.
} 
$\left(G D P G R W_{t}\right)$, unemployment rate growth $\left(U N E M P G R W_{t}\right)$ and return on the national home price index $\left(C S R E T_{t}\right)$, are significantly correlated with PU Index ${ }_{t}$.

Figure 2 plots the BBD (2016) PU index with the aggregate level of loan loss provisions measured at the quarterly median value. The figure indicates that when PU increases (decreases), the aggregate level of loan loss provisions also increases (decreases). This visual pattern lends initial support to our hypothesis that the relation between PU and loan loss provisions is positive.

\section{Empirical results}

\subsection{Main findings}

Table 2 presents the results of testing $\mathrm{H} 1$ via the estimation of Equation (1). In the baseline model, we regress loan loss provisions $\left(L L P_{i, t}\right)$ on the PU index (PU Index $)$ and other control variables. In Table 2 (and the remaining tables), we include bank fixed effects and report t-statistics based on robust standard errors clustered by bank and quarter.

We start our baseline analysis with each component of PU and then move on to the overall PU index. The BBD (2016) overall PU index is a weighted average index consisting of four components: i) an PU index constructed by a newspaper-based approach, based on 10 leading US newspapers; ii) uncertainty related to tax code expirations; iii) disagreement over CPI forecasts and iv) disagreement over government purchases forecasts. To investigate the effect of each component while avoiding the possible collinearity problem, we run the baseline model with each component separately. As shown in the first four columns of Table 2, the results for each component are consistent with our prediction, i.e., the coefficients on all the PU components are significantly positive. ${ }^{13}$

\footnotetext{
${ }^{13}$ In addition to the newspaper-based index using the 10 leading US newspapers, Baker et al. (2016) provide an alternative policy uncertainty measure that is derived from the Access World News database, which includes over 2,000 US newspapers. We find similar results when using this alternative measure of policy uncertainty.
} 
The results in column (5) also show a positive relation between the overall $P U$ Index $_{t}$ and $L L P_{i, t}$. More specifically, the coefficient on $P U$ Index $_{t}$ is 0.0473 and is significantly different from zero at the $1 \%$ level. As expected, banks’ loan loss provisions are positively associated with macroeconomic uncertainty (MacroUncertainty $)_{t}$. Since we control for this general economic uncertainty, the coefficient on our variable of interest ( $P U$ Index $_{t}$ ) captures the effect due to policy-related uncertainty. The signs of the estimated coefficients for the bank-level control variables are generally consistent with the findings in prior literature. For instance, the changes in nonperforming loans $(\triangle N P L)$ in the past, current and near future are positively associated with the loan loss provisions accrued in the current period $\left(L L P_{i, t}\right)$ and the change in outstanding loans $\left(\triangle L O A N_{i, t}\right)$ and net charge-offs $\left(C O_{i, t}\right)$ in the current quarter also have positive effects. Meanwhile operating performance $\left(E B P_{i, t}\right)$ and loan loss allowance at the beginning of the quarter $\left(A L W_{i, t-1}\right)$ are negatively associated with $L L P_{i, t \cdot}{ }^{14}$

The main results we document above are not only statistically but also economically significant. To show the economic significance of the effect of policy uncertainty on loan loss provisions, we calculate the effect of a one standard deviation change in the overall PU Index .

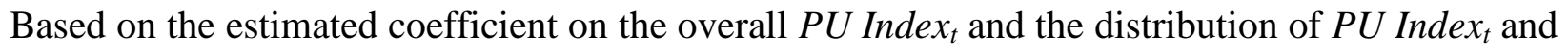
$L L P_{i, t}$, we find that a one standard deviation increase in policy uncertainty is associated with a $11.42 \%$ increase in loan loss provisions. ${ }^{15}$ This magnitude is larger than the effect of future changes in nonperforming loans $\left(\triangle N P L_{i, t+1}\right)$, a previously documented provisions determinant indicating that some bank managers are forward looking (Beatty and Liao, 2011).

\footnotetext{
${ }^{14}$ While the significantly negative coefficient on $E B P_{i, t}$ is inconsistent with earlier studies such as Beatty et al. (1995), Collins et al. (1995) and Liu and Ryan (2006), it is consistent with recent studies such as Beatty and Liao (2011) and Hribar et al. (2017).

${ }^{15}$ The reported percentage is calculated as (regression coefficient $\times$ standard deviation of $P U$ Index $_{t}$ ) / mean value of $L L P_{i, t}$.
} 
Hribar et al. (2017) document that managerial sentiment biases bank managers' accrual estimates. Both the sentiment measure and the PU index are macro-level variables with only time-series variation and both are shown to be correlated with several other macro-level variables, such as GDP growth and the change in the unemployment rate. In the last two columns of Table 2, we further control for managerial sentiment. As a first step, we replicate Hribar et al.'s (2017) results in column (6). Consistent with their main findings, the coefficient on managerial sentiment $\left(B E L I E F S_{t}\right)$ is significantly negative. Next, we rerun the baseline model with additional controls for managerial sentiment and present the results in column (7). We continue to find a significantly positive coefficient on $P U$ Index $t$ after controlling for managerial sentiment. ${ }^{16}$ However, the coefficient on BELIEFS $_{t}$ becomes insignificant. This result is important because it suggests that rational expectations about the depressive effects of policy uncertainty, not managerial sentiments, drive loan loss provisioning.

Overall, the results in Table 2 are consistent with our prediction in H1. We show a positive and significant contemporaneous relation between loan loss provisions and PU, after controlling for various bank-level characteristics as well as several macro-level control variables. Our finding indicates that bank managers are concerned about PU's expected depressive effects and incorporate their expectation into accrual estimates. This finding is also consistent with prior literature that documents the use of loan loss provisions to communicate private information about future loan losses. ${ }^{17}$

\subsection{Robustness tests}

\footnotetext{
${ }^{16}$ The managerial sentiment measure is derived from the Duke University/CFO Magazine Business Outlook survey, which is only available after 2002. We do not control for managerial sentiment in our main specification because doing so would significantly shorten our sample period.

${ }^{17}$ In the latter part of this paper, we provide more evidence using future loan charge-offs and liquidity creation to support the notion that managers do indeed communicate their expectations.
} 
We conduct several additional tests to check the robustness of our main findings. First, to further address the possibility of omitted variable bias in the baseline model and as a means of establishing causality, following Gulen and Ion (2016) and Bonaime et al. (2018), we use an instrumental variable for PU. Specifically, we employ the partisan-conflict index of Azzimonti (2016) from the Federal Reserve Bank of Philadelphia, which is based on a frequency count of newspaper articles containing terms related to lawmakers’ policy disagreements. By construction, partisan conflict should have an impact on policy uncertainty and arguably no direct effect on banks' loan loss provisions. In the first stage, we regress the PU index on the partisan-conflict index and the bank- and macro-level controls used in our main specification. In the second stage, we run the same OLS regression as specified in Equation (1), but with the fitted values from the first stage regressions as the instrumented PU.

Columns (1) and (2) of Table 3 present the results of the 2SLS estimation. In the first stage, the coefficient on the instrumental variable is significantly positive and the F-statistics suggest that the instrument satisfies the relevance condition. In the second stage, we continue to find a positive relation between the instrumented PU and loan loss provisions and the magnitude of the regression coefficient is comparable with that of the baseline results using the overall PU index as shown in column (5) of Table 2. Therefore, our primary results are robust to an IV approach to mitigate omitted variable bias.

In addition, we test whether our baseline results are sensitive to the exclusion of observations from periods of economic difficulties for two reasons. First, PU tends to be higher during these periods and governments try to develop policies to try to revive the economy. As there is often significant uncertainty about their adoption and their effectiveness, there could be a concern that economic difficulties, as opposed to PU, drive loan loss provisioning. Second, 
banks could be under unique circumstances (e.g., governmental intervention in the banking system and bank closures) during periods of economic difficulty and only make additional loan loss provisions as a consequence of these unique circumstances. For example, during the last financial crisis in the United States, the Troubled Asset Relief Program, whose stated objective was to provide financial stability, was also viewed by many as a government bailout of troubled banks.

To ensure that banks are indeed making more loan loss provisions because they anticipate more future loan losses when PU is higher, we rerun our baseline model after removing bankquarter observations during recession periods, as defined by NBER, i.e., observations during the $2^{\text {nd }}$ to $4^{\text {th }}$ quarters of 2001 and from the $4^{\text {th }}$ quarter of 2007 to the $2^{\text {nd }}$ quarter of 2009 . The results in column (3) of Table 3 are qualitatively similar to those reported in column (5) of Table 2 and thus confirm that our main results are robust to the exclusion of the recession period observations.

Alternatively, we rerun our baseline model after removing all bank-quarter observations in the whole period during which lenders and borrowers can be potentially affected by the recent financial crisis, i.e., from the $1^{\text {st }}$ quarter of 2007 to the $4^{\text {th }}$ quarter of 2010 . Column (4) of Table 3 presents the regression results. The coefficient on PU index is significantly positive and the magnitude of the coefficient is comparable with that reported in our main regressions, suggesting that our main findings are not driven by economic difficulties induced by financial crisis.

Taking together, the robustness checks in Table 3 show that our main findings are robust to different specifications and different sample periods.

\section{Cross-sectional tests}

In this section, we first introduce two cross-sectional analyses to examine our additional hypotheses on the conditions under which the relation between PU and loan loss provisions is 
stronger or weaker. The objective of these analyses is to provide deeper insight into our baseline results and to shed light on the channel through which policy uncertainty affects loan loss provisions. To test those cross-sectional hypotheses, we include in Equation (1) an interaction term between policy uncertainty and each measure of bank risk or sufficiency of prior loan loss reserves. Our focus is on the coefficients of those interaction terms.

\subsection{The role of bank risk}

In H2, we investigate whether the relation between PU and loan loss provisions varies for banks with different levels of risk. We focus on loan portfolio and regulatory-capital-related risk because those are the most important types of risk for banks. We argue that loan portfolio risk, to some extent, reflects lenders’ risk management as well as borrowers' financial health and thus the ability to deal with the depressive effects of policy uncertainty. Therefore, we posit that banks with higher loan portfolio risk are more heavily affected by PU. To test this hypothesis, we start with two distinct proxies that capture different aspects of loan portfolio risk, i.e., i) the percentage of nonperforming loans and ii) loan type diversification.

Disclosure of nonperforming assets is an informative and useful aid in analyzing banks’ asset quality (Meeker and Gray, 1987; Beaver et al., 1989), hence we use the percentage of nonperforming loans as our first proxy for loan portfolio risk. Specifically, we define this variable, $N P L_{t-1}$, as the last quarter's nonperforming loans scaled by total outstanding loans. To ease the interpretation of the coefficient on the interaction term, we create a dummy variable, High, to differentiate between banks with higher vs. lower loan portfolio risk. High equals 1 if a bank-quarter observation has a value of $N P L_{i, t-1}$ that is greater than the median value, otherwise 0 . By construction, observations with a higher percentage of nonperforming loans $($ High $=1)$ will have higher loan portfolio risk. 
The extent to which PU adversely affects the economy can be different for different regions or types of borrowers. Therefore, the credit risks of the outstanding loans allocated to different types of borrowers are probably not perfectly correlated with each other and hence are at least partially diversifiable. Jayaratne and Strahan (1996) document an improvement in bank lending after US banking regulators relaxed restrictions on intrastate branching, which impeded geographic diversification. Conversely, customer concentration increases industrial companies' risk and cost of capital (Dhaliwal et al., 2016; Campello and Gao, 2017), while loan type concentration increases the probability of bank failure (Ng and Roychowdhury, 2014). Multimarket banks smooth local exogenous shocks by reallocating their credit supply between affected and unaffected markets (Cortés and Strahan, 2017). ${ }^{18}$ Thus, we consider the extent of loan type diversification as our second proxy of loan portfolio risk. Specifically, we define loan type diversification as one minus the Herfindahl index of the distribution of real estate loans, commercial and industrial loans; loans to depository institutions; agricultural loans; loans to individuals and loans to foreign governments. Based on the lagged loan type diversification measure $\left(L D I V_{i, t-1}\right)$, the dummy variable High is coded as 1 if the bank-quarter observation has a value of $L D I V_{i, t-1}$ that is greater than the median value, otherwise 0 . Banks with a larger value of $L D I V_{i, t-1}$ are more diversified $(H i g h=1)$, in the sense that the outstanding loans are more evenly distributed across different categories of borrowers.

Besides the loan portfolio risk, we consider the regulatory-capital-related risk since the banking industry is heavily regulated and minimum regulatory capital is the most important requirement. Capital adequacy is a key element of the safe and soundness of banks and one that bank regulators have long emphasized (Burhouse et al., 2003). Since bank regulators impose

\footnotetext{
${ }^{18}$ When PU rises, more diversified banks not only have a lower ex-ante credit risk but also enjoy more ex-post flexibility in lending reallocation.
} 
only a minimum capital ratio, bank managers have discretion with regard to maintaining capital ratios well above the minimum requirement. Therefore, the actual capital ratio level is endogenously determined by bank managers. Consistent with the view that higher capital adequacy reflects more prudence or less excessive risk-taking, recent empirical studies show that banks with a higher capital ratio are less likely to fail or to receive enforcement letters ( $\mathrm{Ng}$ and Roychowdhury, 2014; Akins et al., 2016) and they enjoy a lower funding cost and are less risky (Levine, Lin and Xie, 2016; Goetz, Laeven and Levine, 2016). To test our hypothesis from the perspective of regulatory-capital-related risk we use the tier 1 risk-based capital ratio defined in the Basel Capital Accord. The tier 1 capital ratio is calculated as core capital, including common equity, perpetual preferred stock, etc., divided by risk-weighted assets. The ratio is quarterly filed with bank regulators, as all banks need to meet the required minimum. Based on the lagged tier 1 risk-based capital ratio $\left(C A P R 1_{i, t-1}\right)$, the dummy variable High is coded as 1 if a bank-quarter observation has a value that is greater than the quarterly median, otherwise 0 .

Table 4 presents the results of these cross-sectional tests. Consistent with our prediction in H2, the coefficients on $P U$ Index $_{t} \times$ High are statistically significant and have the expected signs. Column (1) shows the results of using the percentage of nonperforming loans as our first measure of loan portfolio risk: the coefficient on PU Index $x_{t}$ is 0.0261 and the coefficient on PU Index $_{t} \times$ High is 0.0494 , both positive and significant at the $1 \%$ level. Therefore, the effect of policy uncertainty on loan loss provision is much larger for banks with higher nonperforming loans: the total magnitude equals to 0.0756 (i.e., 0.0261 plus $0.0494 \times 1$ ), compared to that of banks with lower nonperforming loans, 0.0261 (i.e., 0.0261 plus $0.0494 \times 0$ ). Column (2) presents the results using loan type diversification as our second measure of loan portfolio risk 
and the results are consistent with our second hypothesis. ${ }^{19}$ As expected, the coefficient on the interaction term in column (3) is significantly negative since the higher tier 1 risk-based capital ratio represents a lower capital-related risk. Collectively, considering loan portfolio risk as well as regulatory-capital-related risk, we find corroborating evidence that supports our prediction that the positive effect of policy uncertainty on loan loss provisions is stronger for riskier banks. The moderating effects of loan portfolio and regulatory risk indicates that when making loan loss accrual estimates, bank managers take into account the bank’s own risk level.

\subsection{The role of prior reserves}

In H3, we exploit the variation in the sufficiency of prior loan loss reserves to investigate whether the effect of PU on loan loss provisions differs across banks. Since the sufficiency of prior loan loss reserves is close to the concept of timeliness in loan loss recognition, which is a specific kind of accounting conservatism shown to be beneficial to banks in terms of mitigating downside risk, we expect timelier banks that have accrued more losses into the allowance in the past will not need to record the same level of current-period loan loss provisions as do other banks. In short, we predict that the effect of policy uncertainty on loan loss provisions will be weaker for banks with more prior loan loss reserves.

To test H3, we use two similar but distinct measurements of sufficiency in prior reserves. First, following Beatty and Liao (2011), we define the sufficiency as the ratio of the loan loss allowance divided by nonperforming loans, with both the numerator and denominator taking their values as of quarter $t-1$. This is a useful ratio that reflects a bank's effectiveness in identifying specific impaired loans (Fitch Research, 2009). ${ }^{20}$ Alternatively, we also use net loan

\footnotetext{
19 The coefficients on the interaction terms are significantly negative, as expected, because higher-level risk diversification indicates lower loan portfolio risk.

${ }^{20}$ However, this percentage only takes into account the past level of nonperforming loans. Akins et al. (2017) modify this measure to include the current changes in nonperforming loans, i.e., they compute the loan loss reserves
} 
charge-offs as the scaler, because regulators and analysts use the ratio of the allowance for loan losses to net charge-offs to assess the adequacy of banks loan loss reserves (Liu and Ryan, 2006). Choosing nonperforming loans and charge-offs as alternative scalers involves trade-offs between relevance and reliability: while the amount of nonperforming loans is a more timely measure of loan losses because it takes time to confirm losses and then record them as charge-offs, the charge-offs provide a more reliable indicator of loan losses (Beck and Narayanamoorthy, 2013). To ease the interpretation of the coefficient on the interaction term, we create a dummy variable (High) based on each measurement. High equals 1 if the bank-quarter observation has a value that is greater than the median, otherwise 0 . According to the argument that banks with more prior reserves are better prepared for policy uncertainty, a significant negative coefficient on the interaction term, $P U$ Index ${ }_{t} \times$ High, would support our hypothesis.

Table 5 presents the results of testing hypothesis H3. Consistent with our prediction, we find that the coefficients on PU Index $\times$ $\times$ High are significantly negative for both measurements. For instance, as shown in the first column, the effect of policy uncertainty on loan loss provision is much smaller for banks with more prior reserves: the net magnitude equals 0.0137 (i.e., 0.0619 minus $0.0482 \times 1$ ), compared to that of banks with lower prior reserves, 0.0619 (i.e., 0.0619 minus $0.0482 \times 0$ ). Using two different measures, we get consistent results to support our hypothesis. Our finding in this cross-sectional test sheds new light on the benefit of conservative accounting practice in mitigating the expected adverse effect of policy uncertainty.

\subsection{The impact on future charge-offs}

at quarter t-1 as a percentage of the nonperforming loans at quarter t. We obtain qualitatively similar results using this modified measure. 
Our baseline results suggest that bank managers take PU into account when estimating loan loss provisions. One natural further question is whether the contemporaneous association between PU and loan loss provisions is driven by the rational expectation of future borrowers' defaults or whether it merely reflects behavioral bias. Although the above cross-sectional tests provide corroborating evidence that banks with more exposure are expected to be more heavily affected by PU, indicating that the effect of PU on loan loss provisions tends to be driven by rational expectations, we set forth to provide direct evidence on this question by examining the relation between PU and future realized loan losses, captured by loan charge-offs.

In $\mathrm{H} 4$, we predict that the amount of realized future charge-offs following quarter $\mathrm{t}$ is increasing in the level of quarter $\mathrm{t}$ PU and that this positive relation is more pronounced for banks that make more loan loss provisions in the current quarter. We test this hypothesis by estimating the following pooled OLS model:

$$
\begin{aligned}
& C O_{i, t+1}=\beta_{0}+\beta_{1} P U \text { Index }_{t}+\beta_{2} \text { MacroUncertainty }_{t}+\beta_{3} \Delta N P L_{i, t-2}+\beta_{4} \Delta N P L_{i, t-1} \\
& +\beta_{5} \Delta N P L_{i, t}+\beta_{6} \Delta N P L_{i, t+1}+\beta_{7} S I Z E_{i, t-1}+\beta_{8} \Delta L O A N_{i, t}+\beta_{9} E B P_{i, t}+\beta_{10} C O_{i, t} \\
& +\beta_{11} \operatorname{CAPR}_{i, t-1}+\beta_{12} A L W_{i, t-1}+\beta_{13} \text { EARNINGVOL }_{i, t-1} \\
& +\beta_{14} \text {HOMOGENEITY }_{i, t}+\beta_{15} \text { PUBLIC }_{i, t}+\beta_{16} \text { INTCONTROL }_{i, t} \\
& +\beta_{17} G D P G R W_{t}+\beta_{18} U N E M P G R W_{t}+\beta_{19} C S R E T_{t}+\text { bank fixed effects } \\
& +\varepsilon
\end{aligned}
$$

where $\mathrm{CO}_{i, t+1}$ is the net charge-offs in the next quarter scaled by total outstanding loans and the net charge-off is calculated as the realized loan losses minus recoveries. Alternatively, we also consider the charge-offs in the following year, i.e., 4 calendar quarters, labeled as $\mathrm{CO}_{i, t+1234}$. In Equation (2), our interest is whether and how the current-quarter PU is associated with net charge-offs in subsequent quarter(s). To test whether this prediction varies for banks accruing 
different levels of loan loss provisions, we additionally include an interaction term in Equation (2). Specifically, we create a dummy variable (High) based on the current-quarter loan loss provisions. High is coded as 1 if the current-quarter loan loss provision $\left(L L P_{i, t}\right)$ is greater than the quarterly median value, otherwise 0 . Then we interact the current-quarter PU with this dummy variable, i.e., $P U$ Index $_{t} \times$ High. A significantly positive coefficient on this interaction term would support our hypothesis.

We start by considering the loan charge-offs in the next quarter, i.e., testing whether and how current-quarter policy uncertainty is associated with next-quarter realized loan losses. The first column of Table 6 presents the results of this test by estimating Equation (2). The positive coefficient on $P U$ Index $_{t}$ reveals the predictability of the current policy uncertainty on future realized loan losses and provides direct evidence of the depressive effects of policy uncertainty. More importantly, by including an interaction term in the second column, we find that the effect of current-quarter policy uncertainty on next-quarter charge-offs is significantly larger for banks that accrued more current-quarter loan loss provisions, consistent with our prediction. The significantly positive coefficient on the interaction term, PU Index $\times$ High, provides direct evidence that accruing more loan loss provisions in the current quarter with respect to the contemporaneous higher policy uncertainty is associated with higher future realized loan losses. Therefore, our empirical evidence indicates that the relation between PU and loan loss provisions are likely to reflect bank managers' rational expectation of future loan loss realization and cannot merely be explained by behavioral bias.

To provide robust evidence for this hypothesis and because loan loss realization may take a longer time frame, we consider loan charge-offs in the following 4 quarters, i.e., one calendar year in the future. The last two columns of Table 6 present the results. We find that changing the 
dependent variable to capture loan loss realization in a longer future period does not change our inferences. Collectively, the results in Table 6 provide direct and robust evidence suggesting that the positive relation between PU and loan loss provisions is mainly driven by bank managers' rational expectation of future loan loss realization.

5.4 The impact of PU on future liquidity creation

Finally, we examine H5, which is about the real, as opposed to the accounting, effect of policy uncertainty in terms of banks' liquidity creation. Specifically, from a real effect perspective, we investigate the relation between PU and banks' future liquidity creation. We then investigate whether accounting, in the form of loan loss provisioning, plays a role in this relation. To conduct the analyses, we estimate the following pooled OLS model:

$$
\begin{aligned}
& \Delta L O A N_{i, t+1}=\beta_{0}+\beta_{1} P U \text { Index }_{t}+\beta_{2} \text { MacroUncertainty }_{t}+\beta_{3} \Delta N P L_{i, t-2}+\beta_{4} \Delta N P L_{i, t-1} \\
& +\beta_{5} \Delta N P L_{i, t}+\beta_{6} \Delta N P L_{i, t+1}+\beta_{7} S I Z E_{i, t-1}+\beta_{8} E B P_{i, t}+\beta_{9} C O_{i, t} \\
& +\beta_{10} C A P R 1_{i, t-1}+\beta_{11} A L W_{i, t-1}+\beta_{12} \text { EARNINGVOL }_{i, t-1} \\
& +\beta_{13} \text { HOMOGENEITY }_{i, t}+\beta_{14} \text { PUBLIC }_{i, t}+\beta_{15} \text { INTCONTROL }_{i, t} \\
& +\beta_{16} G D P G R W_{t}+\beta_{17} U N E M P G R W_{t}+\beta_{18} C_{S R E T}+\text { bank fixed effects } \\
& +\varepsilon,
\end{aligned}
$$

where the dependent variable, $\triangle L O A N_{i, t+1}$, is the quarterly change in total outstanding loans from the current to the next quarter. Consistent with the view that PU's depressive effects on borrowers decrease their funding demands as well as banks' credit supply, the results in the first column of Table 7 show that the coefficient on $P U$ Index $x_{t}$ is significantly negative, indicating that banks' lending decreases in response to high $\mathrm{PU} .{ }^{21} \mathrm{By}$ including an interaction term (PU Index $x$ $\times$ High) in Equation (3), where High is a dummy variable coded as 1 if current-quarter

\footnotetext{
${ }^{21}$ This finding is consistent with that documented in Bordo et al. (2016).
} 
loan loss provisions $\left(L L P_{i, t}\right)$ are greater than the quarterly median, we find that banks that accrued more loan loss provisions in the current quarter will reduce lending even more in the next quarter, as suggested by the significant negative coefficient on the interaction term in column (2). In short, the evidence in the first two columns shows that PU does have a negative effect on banks' lending behavior and that accruing more loan loss provisions exacerbates it.

Besides banks’ liquidity creation being directly captured by the change in outstanding loans, we also consider Berger and Bouwman's (2009) total liquidity creation measure (TotalLC $\left.C_{i, t+1}\right)$ and liquidity creation through off-balance-sheet activities $\left(\right.$ OffBSLC $\left.C_{i, t+1}\right) .{ }^{22} \mathrm{We}$ replace the independent variable in Equation (3) with those two liquidity creation measures and report the results in the last four columns of Table 7. The results in columns (3) and (5) show that policy uncertainty is negatively associated with both measures of liquidity creation. ${ }^{23}$ When adding the interaction term, $P U$ Index $_{t} \times$ High, into the regression model in columns (4) and (6), we find that the coefficients on the interaction terms are significantly negative for both liquidity creation measures. Therefore, using alternative measures of liquidity creation does not change our inferences.

Collectively, the results in Table 7 show that PU has a real effect on banks' liquidity creation activities and that the level of loan loss provisions plays an important role in moderating this effect. These findings further corroborate our economic-based explanation of the relation between PU and loan loss provisions.

\section{The effect of PU due to regulatory, fiscal and monetary policy}

\footnotetext{
${ }^{22}$ Berger and Bouwman (2009, p. 3840) report that "banks create almost half of their liquidity off the balance sheet."

${ }^{23}$ In a concurrent paper using the same liquidity creation measures, Berger et al. (2018) also document that economic policy uncertainty harms the real economy through decreasing bank liquidity creation.
} 
The results in the previous section strongly support the hypothesis that policy uncertainty affects loan loss provisioning through their expected depressive effects. In this section, we analyze whether the positive impact of policy uncertainty on loan loss provisioning depends on the type of policy generating the uncertainty. Baker et al. (2016) consider eleven categoryspecific indices of policy uncertainty related to fiscal policy, taxes, government spending, monetary policy, regulation, financial regulation, health care, entitlement programs, national security, trade policy and sovereign debt. To obtain these measures, the authors count newspaper articles that contain search terms related to the specific type of policy in question in addition to the original search terms for the overall policy uncertainty index. Baker et al. (2016) and Bonaime et al. (2018) find that fiscal (including taxes and government spending), regulatory and monetary policy are most important generators of policy uncertainty.

The model specification is the same as our main tests, e.g., we control for macroeconomic uncertainty and macro-level economic condition as well as several of the banklevel determinants of loan loss provisions suggested by prior literature. To avoid the multicollinearity problem, we consider policy uncertainty due to regulatory, fiscal and monetary policy separately. Table 8 presents the results of this additional analysis. The regression results in columns (1) and (2) show that the level of banks' loan loss provisions is positively associated with regulatory and fiscal policy uncertainty, respectively. Specifically, the coefficient on regulatory (fiscal) policy uncertainty is $0.0305(0.0203)$ and both are statistically significant at the $1 \%$ level. As shown in column (3), the regression coefficient on monetary policy uncertainty is also positive although not significant.

One might find the lack of a significant result for monetary policy uncertainty surprising. One explanation for the insignificant result is that uncertainty in monetary policy might have a 
limited impact on loan loss provisions because monetary policy uncertainty, particularly uncertainty in interest rates, might have a limited effect on existing borrowers' willingness and ability to repay their existing loans. In addition, borrowers and banks might be able to hedge against interest rate uncertainty via interest rate swaps or credit default swaps (Guay, 1999; Campello et al., 2011; Rampini et al., 2017), which, in turn, mitigates the likelihood and/or extent to which monetary policy uncertainty per se impacts future loan losses and thus current loan loss provisions. In contrast, it is likely to be more difficult to hedge against the potential depressive effects that arise in response to fiscal and regulatory policy uncertainty. ${ }^{24}$

Overall, exploiting policy uncertainty due to the three most important types of specific policy, we provide additional evidence that policy uncertainty is positively associated with loan loss provisions.

\section{Conclusion}

In this paper, we investigate the association between PU and accrual estimates in the banking industry. Using a sample of all US commercial banks' quarterly observations from 1996 to 2016, we examine whether and how PU affects banks' loan loss provisions. In our primary tests, we use the BBD (2016) overall PU index and find that the contemporaneous relation between PU and loan loss provisions is positive. Our results are both statistically and economically significant, consistent for each component of the overall PU index and robust to the instrumental variable approach and other robustness checks.

Cross-sectional tests further suggest that the loan loss provisions of banks with higher risk and smaller prior reserves are likely to be more heavily affected by policy uncertainty. In

\footnotetext{
${ }^{24}$ Further untabulated analyses of the relation between monetary policy uncertainty and loan loss provisions show that for banks with a high risk level or with low prior reserves, monetary policy uncertainty has a significantly positive effect on such banks' loan loss provisions. Hence, while there is no signification association between monetary policy uncertainty and loan loss provisions on average, there is a positive association on certain subsets of banks.
} 
addition to this corroborating evidence, by further linking policy uncertainty to future loan loss realization, we provide direct evidence that the positive association between PU and loan loss provisions reflects managers' rational response to future economic conditions. Taken together, when policy uncertainty is high, bank managers rationally expect more loan losses to be realized in the future, leading them to accrue more loan loss provisions in the current quarter.

This study adds to the growing body of PU literature by showing that policy uncertainty can also affect accrual estimates. It also contributes to the banking literature by examining the adverse effects of PU on banks' loan portfolios. This is an important issue because the accrued loan losses can lead to a capital crunch and reduced lending in the economy (Beatty and Liao, 2011), which, in turn, can magnify PU’s depressive effects. Our cross-sectional results shed new light on how banks can mitigate their loan portfolio exposure to PU.

The positive association between PU and loan loss provisions indicates that when making loan loss provisions, at least some banks are already forecasting future loan losses in response to the current PU level. We believe that the results of this study should be of interest to standard setters and regulators, given the longstanding debate over accounting for credit losses (e.g., Bikker and Metzemakers, 2005; Beatty and Liao, 2011; Bushman and Williams, 2012; Bouvatier and Lepetit, 2012) and the newly introduced current expected credit loss model (FASB, 2016). Even though we have shown that bank managers rationally respond to PU by accruing more loan losses, it is still unclear whether and how PU impacts the accuracy of accrual estimates. We leave this question to future research. 


\section{References}

Acharya, V., \& Naqvi, H. (2012). The seeds of a crisis: a theory of bank liquidity and risk taking over the business cycle. Journal of Financial Economics, 106(2), 349-366.

Ahmed, A. S., Takeda, C., \& Thomas, S. (1999). Bank loan loss provisions: a reexamination of capital management, earnings management and signaling effects. Journal of accounting and economics, 28(1), 1-25.

Akins, B., Dou, Y., \& Ng, J. (2017). Corruption in bank lending: The role of timely loan loss recognition. Journal of Accounting and Economics, 63(2-3), 454-478.

Akins, B., Li, L., Ng, J., \& Rusticus, T. O. (2016). Bank competition and financial stability: Evidence from the financial crisis. Journal of Financial and Quantitative Analysis, 51(01), $1-28$.

American Institute of Certified Public Accountants (AICPA). (1983). Audits of Banks. New York, NY.

Azzimonti, M. (2016). Partisan conflict and private investment (No. w21273). National Bureau of Economic Research.

Bachmann, R., Elstner, S., \& Sims, E. R. (2013). Uncertainty and economic activity: Evidence from business survey data. American Economic Journal: Macroeconomics, 5(2), 217-249.

Baker, S. R., \& Bloom, N. (2013). Does uncertainty reduce growth? Using disasters as natural experiments (No. w19475). National Bureau of Economic Research.

Baker, S. R., Bloom, N., Canes-Wrone, B., Davis, S. J., \& Rodden, J. (2014). Why Has US Policy Uncertainty Risen Since 1960? American Economic Review, 104(5), 56-60.

Baker, S. R., Bloom, N., \& Davis, S. J. (2016). Measuring economic policy uncertainty. The Quarterly Journal of Economics, 131(4), 1593-1636.

Beatty, A., Chamberlain, S., Magliolo, J., (1995). Managing financial reports of commercial banks: the influence of taxes, regulatory capital and earnings. Journal of Accounting Research 33 (2), 231-262.

Beatty, A. L., Ke, B., \& Petroni, K. R. (2002). Earnings management to avoid earnings declines across publicly and privately held banks. The Accounting Review, 77(3), 547-570.

Beatty, A., \& Liao, S. (2011). Do delays in expected loss recognition affect banks' willingness to lend? Journal of Accounting and Economics, 52(1), 1-20.

Beatty, A., \& Liao, S. (2014). Financial accounting in the banking industry: A review of the empirical literature. Journal of Accounting and Economics, 58(2), 339-383.

Beaver, W., Eger, C., Ryan, S., \& Wolfson, M. (1989). Financial reporting, supplemental disclosures, and bank share prices. Journal of Accounting Research, 27(2), 157-178. 
Beaver, W. H., \& E. E. Engel. (1996). Discretionary behavior with respect to allowances for loan losses and the behavior of security prices. Journal of Accounting and Economics, 22(1-3), 177-206.

Beck, P. J., \& Narayanamoorthy, G. S. (2013). Did the SEC impact banks' loan loss reserve policies and their informativeness? Journal of Accounting and Economics 56(2-3): 42-65.

Berger, A. N., \& Bouwman, C. H. (2009). Bank liquidity creation. The review of financial studies, 22(9), 3779-3837.

Berger, A. N., \& Bouwman, C. H. (2017). Bank liquidity creation, monetary policy, and financial crises. Journal of Financial Stability, 30, 139-155.

Berger, A. N., \& Sedunov, J. (2017). Bank liquidity creation and real economic output. Journal of Banking \& Finance, 81(9), 1-19.

Berger, A. N., Guedhami, O., Kim, H. H., \& Li, X. (2018). Economic policy uncertainty and bank liquidity creation. Working paper.

Bernanke, B. S. (1983). Irreversibility, uncertainty, and cyclical investment. The Quarterly Journal of Economics, 98(1), 85-106.

Bhagat, S., \& Obreja, I. (2013). Employment, corporate investment and cash flow uncertainty. Working paper.

Bikker, J. A., \& Metzemakers, P. A. J. (2005). Bank provisioning behaviour and procyclicality. Journal of International Financial Markets, Institutions and Money, 15(2), 141-157.

Bloom, N. (2009). The impact of uncertainty shocks. Econometrica, 77(3), 623-685.

Bloom, N., Floetotto, M., Jaimovich, N., Saporta-Eksten, I., \& Terry, S. J. (2012). Really uncertain business cycles (No. w18245). National Bureau of Economic Research.

Bonaime, A. A., Gulen, H., \& Ion, M. (2018). Does policy uncertainty affect mergers and acquisitions? Journal of Financial Economics, forthcoming.

Boot, A.W.A., Greenbaum, S. I., \& Thakor, A. V. (1993). RPUtation and discretion in financial contracting. American Economic Review, 83(5), 1165-1183.

Bordo, M. D., Duca, J. V., \& Koch, C. (2016). Economic policy uncertainty and the credit channel: Aggregate and bank level US evidence over several decades. Journal of Financial Stability, 26, 90-106.

Bouvatier, V., \& Lepetit, L. (2012). Provisioning rules and bank lending: A theoretical model. Journal of Financial Stability, 8(1), 25-31.

Brogaard, J., \& Detzel, A. (2015). The asset-pricing implications of government economic policy uncertainty. Management Science, 61(1), 3-18. 
Burhouse, S., Feid, J., French, G., \& Ligon, K. (2003). Basel and the evolution of capital regulation: Moving forward, looking back. Federal Deposit Insurance Corporation. Available at https://www.fdic.gov/bank/analytical/fyi/2003/011403fyi.html

Bushman, R. M., \& Williams, C. D. (2012). Accounting discretion, loan loss provisioning, and discipline of banks' risk-taking. Journal of Accounting and Economics, 54(1), 1-18.

Bushman, R. M., \& Williams, C. D. (2015). Delayed expected loss recognition and the risk profile of banks. Journal of Accounting Research, 53(3), 511-553.

Campbell, A. (2007). Bank insolvency and the problem of nonperforming loans. Journal of Banking Regulation, 9(1), 25-45.

Campello, M., \& Gao, J. (2017). Customer concentration and loan contract terms. Journal of Financial Economics, 123(1), 108-136.

Campello, M., Lin, C., Ma, Y., \& Zou, H. (2011). The real and financial implications of corporate hedging. The journal of finance, 66(5), 1615-1647.

Chi, Q., \& Li, W. (2017). Economic policy uncertainty, credit risks and banks' lending decisions: Evidence from Chinese commercial banks. China Journal of Accounting Research, 10(1), 33-50.

Cohen, L. J., Cornett, M. M., Marcus, A. J., \& Tehranian, H. (2014). Bank earnings management and tail risk during the financial crisis. Journal of Money, Credit and Banking, 46(1), 171-197.

Collins, J., Shackelford, D., Wahlen, J., (1995). Bank differences in the coordination of regulatory capital, earnings and taxes. Journal of Accounting Research 33 (2), 263-292.

Cortés, K. R., \& Strahan, P. E. (2017). Tracing out capital flows: How financially integrated banks respond to natural disasters. Journal of Financial Economics, 125(1), 182-199.

Demirgüç-Kunt, A. \& Detragiache, E. (1998). The determinants of banking crises in developing and developed countries. IMF Economic Review, 45(1), 81-109.

Demirgüç-Kunt, A., Detragiache, E., \& Gupta, P. (2006). Inside the crisis: An empirical analysis of banking systems in distress. Journal of International Money and Finance, 25(5), 702718.

Dhaliwal, D., Judd, J. S., Serfling, M., \& Shaikh, S. (2016). Customer concentration risk and the cost of equity capital. Journal of Accounting and Economics, 61(1), 23-48.

Dye, R. A. (1988). Earnings management in an overlapping generations model. Journal of Accounting Research, 26(2), 195-235.

FASB. (2012). Exposure draft proposed accounting standards update: financial instrumentscredit losses (Subtopic 825-15). December 20. 
FASB. (2016). Update 2016-13: Financial Instruments - Credit Losses (Topic 326): Measurement of Credit Losses on Financial Instruments. (http://www.fasb.org/jsp/FASB/Document_C/DocumentPage?cid=1176168232528\&acce ptedDisclaimer=true).

Federal Open Market Committee. (2009). Minutes of the December Meeting. Available at https://www.federalreserve.gov/monetarypolicy/files/fomcminutes20091216.pdf.

Federal Financial Institutions Examination Council (FFIEC). (1993). Interagency Policy Statement on Allowance for Loan and Lease Losses. December 21. (Reprinted as an Appendix to the Comptroller of the Currency's June 1996 - May 1998 Handbook: Allowance for Loan and Lease Losses: 34-43.).

Fischer, P. E., \& Verrecchia, R. E. (2000). Reporting bias. The Accounting Review, 75(2), 229245.

Fitch Research. (2009). A universal spreadsheet for bank analysis. Available at http://www.alacrastore.com/fitch-credit-research/A-Universal-Spreadsheet-for-BankAnalysis-432622_report_frame.

Goetz, M. R., Laeven, L., \& Levine, R. (2016). Does the geographic expansion of banks reduce risk? Journal of Financial Economics, 120(2), 346-362.

Gow, I.D, Ormazabal, G, \& Taylor, D. J. (2010). Correcting for cross-sectional and time-series dependence in accounting research. The Accounting Review, 85(2): 483-512.

Graham, J. R., Harvey, C. R., \& Rajgopal, S. (2005). The economic implications of corporate financial reporting. Journal of Accounting and Economics, 40(1), 3-73.

Guay, W. R. (1999). The impact of derivatives on firm risk: An empirical examination of new derivative users1. Journal of Accounting and Economics, 26(1-3), 319-351.

Gulen, H., \& Ion, M. (2016). Policy uncertainty and corporate investment. Review of Financial Studies, 29(3), 523-564.

Healy, P. M., \& Wahlen, J. M. (1999). A review of the earnings management literature and its implications for standard setting. Accounting Horizons, 13(4), 365-383.

Hribar, P., Melessa, S. J., Small, R. C., \& Wilde, J. H. (2017). Does managerial sentiment affect accrual estimates? Evidence from the banking industry. Journal of Accounting and Economics, 63(1), 26-50.

International Monetary Fund. (2012). World Economic Outlook: Coping with High Debt and Sluggish Growth. Washington, D.C., IMF Press.

International Monetary Fund. (2013). World Economic Outlook: Hopes, Realities, Risks, Washington, D.C., IMF Press.

Jayaratne, J., \& Strahan, P. E. (1996). The finance-growth nexus: Evidence from bank branch deregulation. The Quarterly Journal of Economics, 111(3), 639-670. 
Jiménez, G., \& Ongena, S., Peydró, J., and Saurina, J. (2012). Credit supply and monetary policy: Identifying the bank balance-sheet channel with loan applications. American Economic Review, 102(5), 2301-2326.

Jung, W. O., \& Kwon, Y. K. (1988). Disclosure when the market is unsure of information endowment of managers. Journal of Accounting Research, 26(1), 146-153.

Jurado, K., Ludvigson, S. C., \& Ng, S. (2015). Measuring uncertainty. American Economic Review, 105(3), 1177-1216.

Kanagaretnam, K., Lobo, G. J., \& YANG, D. H. (2004). Joint tests of signaling and income smoothing through bank loan loss provisions. Contemporary Accounting Research, 21(4), 843-884.

Kanagaretnam, K., Lobo, G. J., \& Yang, D. H. (2005). Determinants of signaling by banks through loan loss provisions. Journal of Business Research, 58(3), 312-320.

Kashyap, A. K., Rajan, R., \& Stein, J. C. (2002). Banks as liquidity providers: an explanation for the co-existence of lending and deposit-taking. Journal of Finance, 57(1), 33-73.

Kashyap, A. K., \& Stein, J. C. (2000). What do a million observations on banks say about the transmission of monetary policy? American Economic Review, 407-428.

Kim, H., \& Kung, H. (2017). The asset redeployability channel: How uncertainty affects corporate investment. Review of Financial Studies, 30 (1), 245-280.

Knaup, M., \& Wagner, W. (2012). A market-based measure of credit portfolio quality and banks' performance during the subprime crisis. Management Science, 58(8), 1423-1437.

Kothari, S. P., Shu, S., \& Wysocki, P. D. (2009). Do managers withhold bad news? Journal of Accounting Research, 47(1), 241-276.

Levine, R., Lin, C., \& Xie, W. (2016). Geographic Diversification and Banks' Funding Costs. Working paper No. w22544, National Bureau of Economic Research.

Levine, R., \& Zervos, S. (1998). Stock markets, banks, and economic growth. American Economic Review, 88(3), 537-558.

Liu, C. C., Ryan, S. G., \& Wahlen, J. M. (1997). Differential valuation implications of loan loss provisions across banks and fiscal quarters. Accounting Review, 133-146.

Liu, C. C., \& Ryan, S. G. (2006). Income smoothing over the business cycle: Changes in banks' coordinated management of provisions for loan losses and loan charge-offs from the pre1990 bust to the 1990s boom. The Accounting Review, 81(2), 421-441.

Louzis, D. P., Vouldis, A. T., \& Metaxas, V. L. (2012). Macroeconomic and bank-specific determinants of nonperforming loans in Greece: A comparative study of mortgage, business and consumer loan portfolios. Journal of Banking \& Finance, 36(4), 1012-1027. 
Meeker, L. G., \& Gray, L. (1987). A note on nonperforming loans as an indicator of asset quality. Journal of Banking \& Finance, 11(1), 161-168.

Moyer, S. E. (1990). Capital adequacy ratio regulations and accounting choices in commercial banks. Journal of Accounting \& Economics, 13(2), 123-154.

Nagar, V., Schoenfeld, J. and Wellman, L. (2017). Economic Policy Uncertainty, Information Asymmetry, and Firm Disclosure. Ross School of Business Paper No. 1333. Available at SSRN: https://ssrn.com/abstract=2841442

Ng, J., \& Roychowdhury, S. (2014). Do loan loss reserves behave like capital? Evidence from recent bank failures. Review of Accounting Studies, 19(3), 1234-1279.

Nguyen, N. H., \& Phan, H. V. (2017). Policy uncertainty and mergers and acquisitions. Journal of Financial and Quantitative Analysis, 52(2), 613-644.

Petersen, M. A. (2009). Estimating standard errors in finance panel data sets: Comparing approaches. Review of Financial Studies, 22(1), 435-480.

Rampini, A. A., Viswanathan, S., \& Vuillemey, G. (2017). Risk management in financial institutions. Working paper

Scholes, M. S., Wilson, G. P., \& Wolfson, M. A. (1990). Tax planning, regulatory capital planning, and financial reporting strategy for commercial banks. The Review of Financial Studies, 3(4), 625-650.

SEC. (2001). SEC Staff Accounting Bulletin: No. 102 - Selected Loan Loss Allowance Methodology and Documentation Issues (Release No. SAB 102). Available at https://www.sec.gov/interps/account/sab102.htm

Starks, L. T., and Sun, S. Y. (2016). Economic Policy Uncertainty, Learning and Incentives: Theory and Evidence on Mutual Funds. Working paper, University of Texas at Austin.

Stein, L. C.D. and Wang, C. C. Y. (2016). Economic Uncertainty and Earnings Management. Working paper, Available at SSRN: https://ssrn.com/abstract=2746091

Wahlen, J. M. (1994). The nature of information bank loan in commercial loss disclosures. The Accounting Review, 69(3), 455-478. 


\section{Appendix A: Variable Definitions and Data Sources}

\begin{tabular}{|c|c|c|}
\hline Variable & Definition & Data Source \\
\hline$L L P_{i, t}$ & $\begin{array}{l}\text { Loan loss provisions in quarter t scaled by the lagged total loans of bank } \\
\text { i. }\end{array}$ & Call Reports \\
\hline PU Index & $\begin{array}{l}\text { The natural log of the quarterly average overall index of policy } \\
\text { uncertainty in quarter t, divided by 100. The Policy Uncertainty Index is } \\
\text { introduced in Baker, Bloom and Davis (2016). The overall PU index is } \\
\text { constructed based on the weighted average of four components: the } \\
\text { frequency of newspaper articles containing key terms related to policy } \\
\text { uncertainty, uncertainty about future changes in the federal tax code } \\
\text { measured by the dollar impact of tax provisions set to expire in the near } \\
\text { future, the dispersion in the economic forecasts of government spending } \\
\text { and the Consumer Price Index (CPI) as a proxy for uncertainty about } \\
\text { future fiscal and monetary policy. }\end{array}$ & $\begin{array}{l}\text { Publicly } \\
\text { available online: } \\
\text { http://policyuncertain } \\
\text { ty.com }\end{array}$ \\
\hline MacroUncertainty $_{t}$ & $\begin{array}{l}\text { Macroeconomic uncertainty constructed following Bonaime, Gulen and } \\
\text { Ion (2018), i.e., the first principal component extracted from the } \\
\text { following four variables: (1) the JLN uncertainty index developed by } \\
\text { Jurado et al. (2015) as the unforecastable component in a system of } 279 \\
\text { macroeconomic variables; (2) the VXO index of implied volatility } \\
\text { released by the Chicago Board Options Exchange; (3) the cross-sectional } \\
\text { standard deviation of cumulative returns during the quarter using the } \\
\text { entire CRSP universe and (4) the cross-sectional standard deviation of } \\
\text { year-on-year sales growth using the entire Compustat quarterly universe. }\end{array}$ & $\begin{array}{l}\text { CBOE, CRSP, } \\
\text { Compustat and } \\
\text { JLN updated } \\
\text { data: } \\
\text { https://www.sydneylu } \\
\text { dvigson.com/data- } \\
\text { and-appendixes/ }\end{array}$ \\
\hline$\triangle N P L_{i, t-2}$ & $\begin{array}{l}\text { The change in nonperforming loans from quarter t-3 to quarter } \mathrm{t}-2 \text { scaled } \\
\text { by total loans in quarter } \mathrm{t}-3 \text {. }\end{array}$ & Call Reports \\
\hline$\triangle N P L_{i, t-1}$ & $\begin{array}{l}\text { The change in nonperforming loans from quarter } \mathrm{t}-2 \text { to quarter } \mathrm{t}-1 \text { scaled } \\
\text { by total loans in quarter } \mathrm{t}-2 \text {. }\end{array}$ & Call Reports \\
\hline$\triangle N P L_{i, t}$ & $\begin{array}{l}\text { The change in nonperforming loans from quarter } \mathrm{t}-1 \text { to quarter } \mathrm{t} \text { scaled } \\
\text { by total loans in quarter } \mathrm{t}-1 \text {. }\end{array}$ & Call Reports \\
\hline$\triangle N P L_{i, t+1}$ & $\begin{array}{l}\text { The change in nonperforming loans from quarter } \mathrm{t} \text { to quarter } \mathrm{t}+1 \text { scaled } \\
\text { by total loans in quarter } \mathrm{t} \text {. }\end{array}$ & Call Reports \\
\hline $\operatorname{SIZE}_{i, t-1}$ & The natural log of total assets at the end of quarter t-1. & Call Reports \\
\hline$\triangle L O A N_{i, t}$ & $\begin{array}{l}\text { The change in total loans from quarter } \mathrm{t}-1 \text { to quarter } \mathrm{t} \text { scaled by total } \\
\text { loans in quarter } \mathrm{t}-1 \text {. }\end{array}$ & Call Reports \\
\hline$E B P_{i, t}$ & $\begin{array}{l}\text { Earnings before taxes and loan loss provisions in quarter t, scaled by } \\
\text { lagged total loans. }\end{array}$ & Call Reports \\
\hline$C O_{i, t}$ & Net charge-off in quarter t scaled by total loans. & Call Reports \\
\hline$C A P R 1_{i, t-1}$ & Tier 1 risk-adjusted capital ratio at the end of quarter $t-1$. & Call Reports \\
\hline$A L W_{i, t-1}$ & Loan loss allowance in quarter t- 1 scaled by total loans in quarter t- 1 . & Call Reports \\
\hline EARNINGVOL $_{i, t-1}$ & $\begin{array}{l}\text { Earnings volatility, calculated as the standard deviation of earnings } \\
\text { before taxes and loan loss provisions (scaled by lagged total loans) }\end{array}$ & Call Reports \\
\hline
\end{tabular}




\begin{tabular}{|c|c|c|}
\hline HOMOGENEITY $_{i, t}$ & $\begin{array}{l}\text { The percentage of homogenous loans out of total outstanding loans at the } \\
\text { end of quarter t. As in Liu and Ryan (2006), homogenous loans refer to } \\
\text { consumer loans, mortgage loans secured by } 1-4 \text { family residential } \\
\text { properties and loans to financial institutions and acceptances of other } \\
\text { banks. }\end{array}$ & Call Reports \\
\hline$\overline{P U B L I C_{i, t}}$ & $\begin{array}{l}\text { Dummy variable that equals } 1 \text { if the bank is a public commercial bank or } \\
\text { a subsidiary of a public bank holding company, } 0 \text { otherwise. }\end{array}$ & $\begin{array}{l}\text { Call Reports and } \\
\text { NIC data }\end{array}$ \\
\hline INTCONTROL $_{i, t}$ & $\begin{array}{l}\text { Dummy variable that equals } 1 \text { if the bank is subject to the FDICIA } \\
\text { internal control provisions, i.e., if the bank is a US insured depository } \\
\text { institution with total assets greater than } \$ 500 \text { million, } 0 \text { otherwise. }\end{array}$ & Call Reports \\
\hline$G D P G R W_{t}$ & $\begin{array}{l}100 \text { times the change in real gross domestic product from quarter t- } 1 \text { to } \\
\text { quarter t scaled by GDP in quarter } \mathrm{t}-1 \text {. }\end{array}$ & $\begin{array}{l}\text { Federal Reserve } \\
\text { Bank of St. Louis }\end{array}$ \\
\hline UNEMPGRW & $\begin{array}{l}\text { The change in the level of the unemployment rate from quarter t- } 1 \text { to } \\
\text { quarter } t \text {. }\end{array}$ & $\begin{array}{l}\text { US Bureau of } \\
\text { Labor Statistics }\end{array}$ \\
\hline $\operatorname{CSRET}_{t}$ & $\begin{array}{l}\text { The quarterly return on the S\&P/Case Shiller US National Home Price } \\
\text { Index, calculated as the change in the index level from quarter } t-1 \text { to } \\
\text { quarter } t \text { scaled by the index level at the end of quarter } \mathrm{t}-1 \text {. }\end{array}$ & $\begin{array}{l}\text { Federal Reserve } \\
\text { Bank of St. Louis }\end{array}$ \\
\hline PartisanConflict $_{t}$ & $\begin{array}{l}\text { The partisan-conflict index of Azzimonti (2016) from the Federal } \\
\text { Reserve Bank of Philadelphia, which is based on a frequency count of } \\
\text { newspaper articles containing terms related to lawmakers' policy } \\
\text { disagreements. We use this partisan-conflict index as the instrumental } \\
\text { variable of policy uncertainty. }\end{array}$ & $\begin{array}{l}\text { Publicly } \\
\text { available online: } \\
\text { https://www.philadelp } \\
\text { hiafed.org/research- } \\
\text { and-data/real-time- } \\
\text { center/partisan- } \\
\text { conflict-index }\end{array}$ \\
\hline
\end{tabular}

This table summarizes the definitions and data sources of the variables used in the regression analyses. 


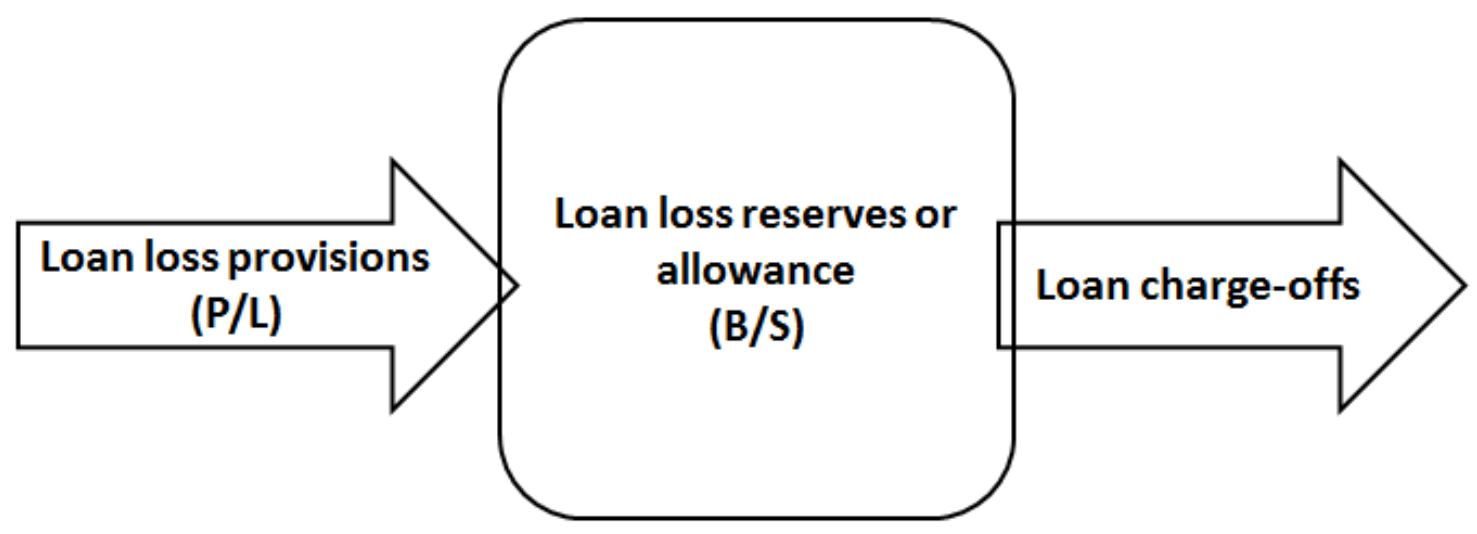

Figure 1. Accounting for credit losses

This figure depicts the relationship between loan loss provisions, the loan loss allowance and loan charge-offs. When a loss-causing event occurs and the amount can be reasonably estimated, bank managers should estimate and present the loan loss provisions in the current period's income statement. Loan loss reserves or allowance is a contra asset account to cumulate the estimated amount of loan losses. When the losses are confirmed in the future, chargeoffs will be made, i.e., to write down the outstanding loans and the corresponding proportion of loan loss reserves. Therefore, a natural link exists between loan loss provisions and future charge-offs, in the sense that a) loan loss provisions increase the pool of reserves while future charge-offs decrease it and, more importantly, b) loan loss provisions, as well as the reserves, are probable and estimated credit losses, while future charge-offs are actually realized losses. 


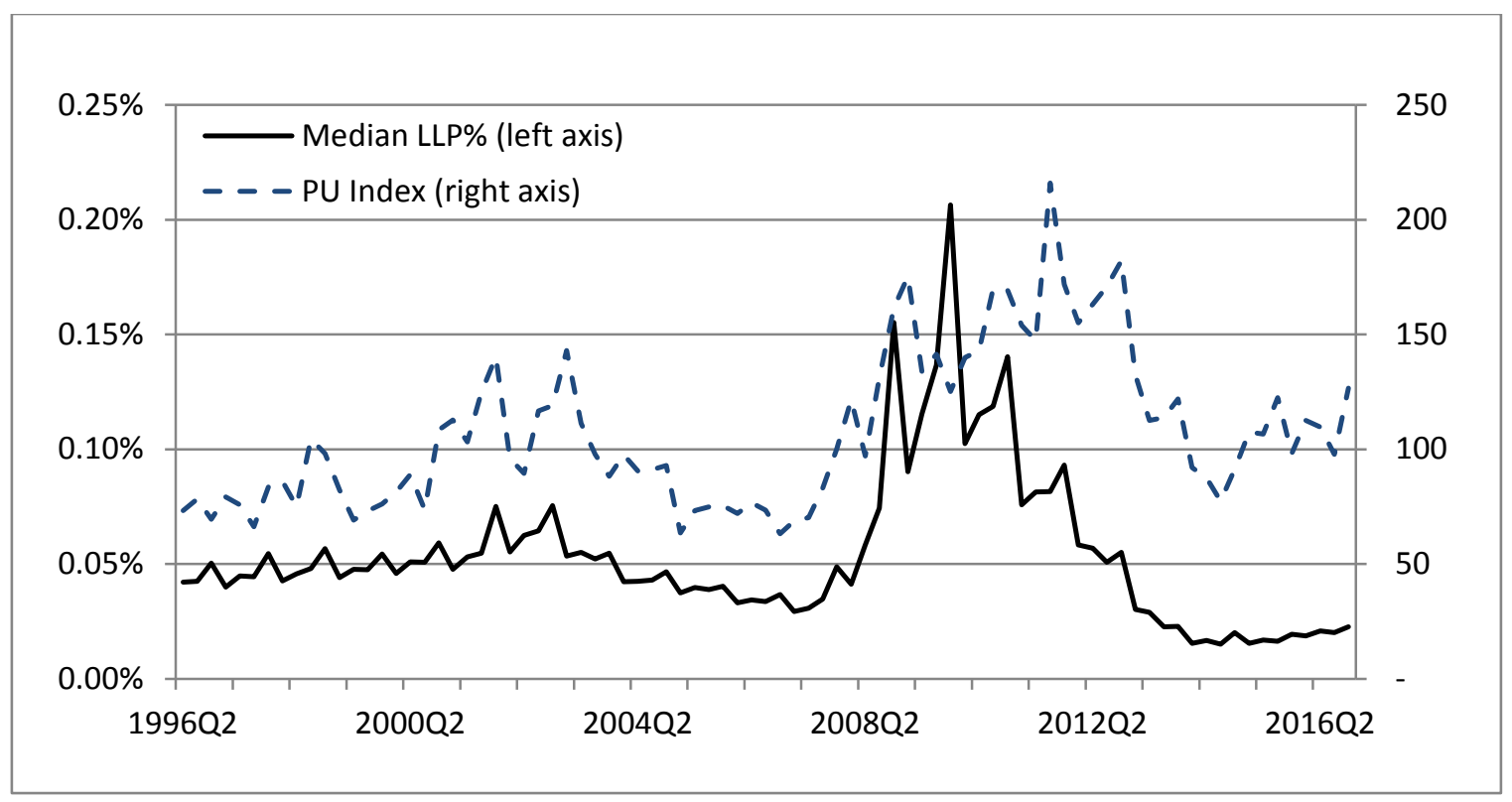

Figure 2

PU index and the aggregate-level loan loss provisions

This figure plots the quarterly median $L L P$, defined as loan loss provisions scaled by lagged total loans, with the BBD (2016) overall policy uncertainty index for the 1996Q2-2016Q4 sample period. 
Table 1

Panel A: Summary statistics

\begin{tabular}{|c|c|c|c|c|c|}
\hline & Mean & S.D. & $25 \%$ & Median & $75 \%$ \\
\hline$L L P_{i, t}$ & 0.0010 & 0.0020 & 0.0000 & 0.0000 & 0.0010 \\
\hline$P U$ Index $_{t}$ & 0.0460 & 0.0030 & 0.0430 & 0.0460 & 0.0480 \\
\hline MacroUncertainty $_{t}$ & 0.0030 & 0.0150 & -0.0090 & -0.0010 & 0.0120 \\
\hline$\Delta N P L_{i, t-2}$ & 0.0000 & 0.0080 & -0.0020 & 0.0000 & 0.0020 \\
\hline$\triangle N P L_{i, t-1}$ & 0.0000 & 0.0080 & -0.0020 & 0.0000 & 0.0020 \\
\hline$\triangle N P L_{i, t}$ & 0.0000 & 0.0080 & -0.0020 & 0.0000 & 0.0020 \\
\hline$\triangle N P L_{i, t+1}$ & 0.0000 & 0.0080 & -0.0020 & 0.0000 & 0.0020 \\
\hline$S I Z E_{i, t-1}$ & 4.8430 & 1.2800 & 3.9650 & 4.7110 & 5.5480 \\
\hline$\triangle L O A N_{i, t}$ & 0.0210 & 0.0590 & -0.0100 & 0.0160 & 0.0440 \\
\hline$E B P_{i, t}$ & 0.0070 & 0.0050 & 0.0040 & 0.0060 & 0.0090 \\
\hline$C O_{i, t}$ & 0.0010 & 0.0020 & 0.0000 & 0.0000 & 0.0010 \\
\hline$C A P R 1_{i, t-1}$ & 0.1660 & 0.0820 & 0.1140 & 0.1410 & 0.1870 \\
\hline$A L W_{i, t-1}$ & 0.0160 & 0.0090 & 0.0110 & 0.0130 & 0.0180 \\
\hline EARNINGVOL $_{i, t-1}$ & 0.0050 & 0.0140 & 0.0010 & 0.0020 & 0.0030 \\
\hline HOMOGENEITY $_{i, t}$ & 0.3980 & 0.2210 & 0.2300 & 0.3690 & 0.5380 \\
\hline PUBLIC $C_{i, t}$ & 0.0990 & 0.2990 & 0.0000 & 0.0000 & 0.0000 \\
\hline INTCONTROL $_{i, t}$ & 0.1320 & 0.3380 & 0.0000 & 0.0000 & 0.0000 \\
\hline$G D P G R W_{t}$ & 0.6210 & 0.6400 & 0.2990 & 0.6780 & 0.9700 \\
\hline$U N E M P G R W_{t}$ & -0.0050 & 0.3000 & -0.1670 & -0.0670 & 0.0670 \\
\hline$C S R E T_{t}$ & 0.0110 & 0.0170 & 0.0050 & 0.0150 & 0.0200 \\
\hline Obs. & & & 059 & & \\
\hline
\end{tabular}

Panel A presents the mean, standard deviation (S.D.), 25th percentile (25\%), median and 75th percentile (75\%) of the variables for the sample period from 1996Q2 to 2016Q4. All continuous variables are winsorized at the 1st and 99th percentiles. Variable definitions are summarized in Appendix A. 
Panel B: Pearson correlations

\begin{tabular}{|c|c|c|c|c|c|c|c|c|c|c|c|c|c|c|}
\hline & 1. & 2. & 3. & 4. & 5. & 6. & 7. & 8. & 9. & 10. & 11. & 12. & 13. & 14. \\
\hline 1. $L L P_{i, t}$ & 1 & & & & & & & & & & & & & \\
\hline 2. PU Index & $0.159^{* * *}$ & 1 & & & & & & & & & & & & \\
\hline 3. MacroUncertainty & $0.145^{* * * *}$ & $0.244^{* * *}$ & 1 & & & & & & & & & & & \\
\hline 4. $\triangle N P L_{i, t-2}$ & $0.092^{* * *}$ & $0.022^{* * *}$ & $0.070^{* * *}$ & 1 & & & & & & & & & & \\
\hline 5. $\triangle N P L_{i, t-1}$ & $0100^{* * * *}$ & $0.011^{* * *}$ & $0.074^{* * *}$ & $-0.123^{* * *}$ & 1 & & & & & & & & & \\
\hline 6. $\triangle N P L_{i, t}$ & $0.061^{* * *}$ & $0.008^{* * *}$ & $0.076^{* * *}$ & $-0.036^{* * *}$ & $-0.120^{* * *}$ & 1 & & & & & & & & \\
\hline 7. $\triangle N P L_{i, t+1}$ & $0.028^{* * *}$ & -0.002 & $0.077^{* * *}$ & $-0.016^{* * *}$ & $-0.035^{* * *}$ & $-0.116^{* * *}$ & 1 & & & & & & & \\
\hline 8. $S I Z E_{i, t-1}$ & $0.101^{* * *}$ & $0.123^{* * *}$ & $-0.078^{* * *}$ & $0.015^{* * *}$ & $0.014^{* * *}$ & $0.012^{* * *}$ & $0.011^{* * *}$ & 1 & & & & & & \\
\hline 9. $\triangle L O A N_{i, t}$ & $0.002^{*}$ & $-0.154^{* * *}$ & $0.009^{* * *}$ & $-0.019^{* * *}$ & $0.004^{* * *}$ & $0.069^{* * *}$ & $0.024^{* * *}$ & $-0.032^{* * *}$ & 1 & & & & & \\
\hline 10. $E B P_{i, t}$ & $-0.027^{* * *}$ & $-0.159^{* * * *}$ & -0.002 & $-0.014^{* * *}$ & $-0.008^{* * *}$ & -0.000 & $0.005^{* * * *}$ & $0.095^{* * *}$ & $0.027^{* * * *}$ & 1 & & & & \\
\hline 11. $C O_{i, t}$ & $0.698^{* * *}$ & $0.167^{* * *}$ & $0.080^{* * *}$ & $0.081^{* * *}$ & $0.086^{* * *}$ & $-0.094^{* * *}$ & $-0.015^{* * *}$ & $0.108^{* * *}$ & $-0.159^{* * *}$ & $-0.021^{* * *}$ & 1 & & & \\
\hline 12. $C A P R 1_{i, t-1}$ & $-0.036^{* * *}$ & $-0.023^{* * *}$ & $-0.043^{* * *}$ & $-0.026^{* * *}$ & $-0.024^{* * *}$ & $-0.019^{* * *}$ & $-0.017^{* * *}$ & $-0.278^{* * *}$ & $0.065^{* * *}$ & $0.197^{* * *}$ & $-0.057^{* * * *}$ & 1 & & \\
\hline 13. $A L W_{i, t-1}$ & $0.220^{* * * *}$ & $0.113^{* * *}$ & $-0.060^{* * *}$ & $-0.011^{* * *}$ & $-0.013^{* * *}$ & $-0.060^{* * *}$ & $-0.071^{* * *}$ & $-0.016^{* * *}$ & $-0.120^{* * *}$ & $0.092^{* * *}$ & $0.364^{* * *}$ & $0.136^{* * *}$ & 1 & \\
\hline 14. EARNINGVOL ${ }_{i, t-1}$ & $0.147^{* * *}$ & 0.001 & $0.054^{* * *}$ & $0.013^{* * *}$ & $0.013^{* * *}$ & $0.012^{* * *}$ & $0.013^{* * *}$ & $-0.074^{* * *}$ & $0.253^{* * *}$ & $-0.059^{* * *}$ & $0.035^{* * *}$ & $0.244^{* * * *}$ & $0.061^{* * *}$ & 1 \\
\hline 15. HOMOGENEITY & $-0.029^{* * *}$ & $-0.093^{* * *}$ & $0.030^{* * *}$ & $-0.009^{* * *}$ & $-0.011^{* * *}$ & $-0.011^{* * *}$ & $-0.012^{* * *}$ & $-0.019^{* * *}$ & $-0.067^{* * *}$ & $0.079^{* * *}$ & $0.005^{* * *}$ & $0.200^{* * *}$ & $-0.138^{* * *}$ & $-0.046^{* * *}$ \\
\hline 16. $P U B L I C_{i, t}$ & $0.038^{* * * *}$ & $-0.047^{* * *}$ & $0.023^{* * *}$ & $0.007^{* * *}$ & $0.007^{* * *}$ & $0.009^{* * *}$ & $0.009^{* * * *}$ & $0.409^{* * *}$ & $0.024^{* * * *}$ & $0.070^{* * *}$ & $0.032^{* * *}$ & $-0.144^{* * *}$ & $0.003^{* *}$ & 0.001 \\
\hline 17. INTCONTROL $L_{i, t}$ & $0.088^{* * *}$ & $0.059^{* * *}$ & $-0.042^{* * *}$ & $0.012^{* * *}$ & $0.012^{* * *}$ & $0.011^{* * *}$ & $0.009^{* * *}$ & $0.705^{* * *}$ & $0.004^{* * *}$ & $0.076^{* * *}$ & $0.091^{* * *}$ & $-0.145^{* * *}$ & $0.035^{* * *}$ & $-0.008^{* * *}$ \\
\hline 18. $G D P G R W_{t}$ & $-0.084^{* * *}$ & $-0.471^{* * *}$ & $-0.397^{* * *}$ & $-0.041^{* * *}$ & $-0.032^{* * *}$ & $-0.061^{* * *}$ & $-0.052^{* * *}$ & $-0.090^{* * *}$ & $0.082^{* * *}$ & $0.138^{* * *}$ & $-0.058^{* * *}$ & $0.031^{* * *}$ & $0.017^{* * *}$ & $-0.013^{* * *}$ \\
\hline 19. UNEMPGRW $W_{t}$ & $0.130^{* * *}$ & $0.303^{* * *}$ & $0.747^{* * *}$ & $0.078^{* * *}$ & $0.085^{* * *}$ & $0.086^{* * *}$ & $0.080^{* * *}$ & $-0.005^{* * *}$ & $-0.016^{* * *}$ & $-0.067^{* * *}$ & $0.073^{* * *}$ & $-0.044^{* * *}$ & $-0.065^{* * *}$ & $0.036^{* * *}$ \\
\hline \multirow[t]{2}{*}{ 20. $C S R E T_{t}$} & $-0.140^{* * *}$ & $-0.344^{* * *}$ & $-0.304^{* * *}$ & $-0.060^{* * *}$ & $-0.064^{* * *}$ & $-0.069^{* * *}$ & $-0.068^{* * *}$ & $-0.073^{* * *}$ & $0.055^{* * *}$ & $0.123^{* * *}$ & $-0.112^{* * *}$ & $0.023^{* * *}$ & $-0.007^{* * *}$ & $-0.016^{* * *}$ \\
\hline & 15. & 16. & 17. & 18. & 19. & 20. & & & & & & & & \\
\hline 15. HOMOGENEITY & 1 & & & & & & & & & & & & & \\
\hline 16. $P U B L I C_{i, t}$ & $0.014^{* * * *}$ & 1 & & & & & & & & & & & & \\
\hline 17. INTCONTROL $L_{i, t}$ & $-0.013^{* * *}$ & $0.403^{* * *}$ & 1 & & & & & & & & & & & \\
\hline 18. $G D P G R W_{t}$ & $0.095^{* * *}$ & $0.025^{* * *}$ & $-0.045^{* * *}$ & 1 & & & & & & & & & & \\
\hline 19. UNEMPGRW & $-0.036^{* * *}$ & $0.004^{* * *}$ & $0.002^{*}$ & $-0.569^{* * *}$ & 1 & & & & & & & & & \\
\hline 20. $\operatorname{CSRET}_{t}$ & $0.093^{* * *}$ & $0.020^{* * * *}$ & $-0.043^{* * *}$ & $0.465^{* * *}$ & $-0.423^{* * *}$ & 1 & & & & & & & & \\
\hline
\end{tabular}

Panel B presents the Pearson correlation for each pair of variables. All continuous variables are winsorized at the 1st and 99th percentiles. Variable definitions are summarized in Appendix A. ${ }^{* * *},{ }^{* *}$ and ${ }^{*}$ represent significance at the $1 \%, 5 \%$ and $10 \%$ levels, respectively. 
Table 2

Main results (Test of H1): The relation between policy uncertainty and loan loss provisions

\begin{tabular}{|c|c|c|c|c|c|c|c|}
\hline Dep.Var. $=L L P_{i, t}$ & $\begin{array}{c}\text { (1) } \\
1^{\text {st }} \text { Comp. }\end{array}$ & $\begin{array}{c}\text { (2) } \\
2^{\text {nd }} \text { Comp. }\end{array}$ & $\begin{array}{c}\text { (3) } \\
3^{\text {rd }} \text { Comp. }\end{array}$ & $\begin{array}{c}\text { (4) } \\
4^{\text {th }} \text { Comp. }\end{array}$ & $\begin{array}{c}\text { (5) } \\
\text { Overall PU }\end{array}$ & (6) & $\begin{array}{c}(7) \\
\text { Overall PU }\end{array}$ \\
\hline PU Index ${ }_{t}$ & $\begin{array}{c}0.0187^{* * *} \\
(2.82)\end{array}$ & $\begin{array}{c}0.0073^{* * *} \\
(5.40)\end{array}$ & $\begin{array}{c}0.0485^{* * *} \\
(3.89)\end{array}$ & $\begin{array}{c}0.0473^{* * *} \\
(6.80)\end{array}$ & $\begin{array}{c}0.0473^{* * *} \\
(6.70)\end{array}$ & & $\begin{array}{c}0.0532^{* * *} \\
(3.50)\end{array}$ \\
\hline BELIEFS $_{t}$ & & & & & & $\begin{array}{c}-0.0036^{* * *} \\
(-3.44)\end{array}$ & $\begin{array}{c}0.0000 \\
(0.03)\end{array}$ \\
\hline MacroUncertainty $_{t}$ & $\begin{array}{c}0.0090^{* * *} \\
(4.14)\end{array}$ & $\begin{array}{c}0.0123^{* * *} \\
(5.69)\end{array}$ & $\begin{array}{c}0.0084^{* * *} \\
(3.52)\end{array}$ & $\begin{array}{c}0.0089^{* * *} \\
(4.60)\end{array}$ & $\begin{array}{c}0.0077^{* * *} \\
(3.54)\end{array}$ & $\begin{array}{c}0.0142^{* * *} \\
(4.12)\end{array}$ & $\begin{array}{c}0.0125^{* * *} \\
(3.37)\end{array}$ \\
\hline$\triangle N P L_{i, t-2}$ & $\begin{array}{c}0.0126^{* * *} \\
(11.37)\end{array}$ & $\begin{array}{c}0.0126^{* * *} \\
(11.29)\end{array}$ & $\begin{array}{c}0.0124^{* * *} \\
(11.61)\end{array}$ & $\begin{array}{c}0.0127^{* * *} \\
(11.96)\end{array}$ & $\begin{array}{c}0.0128^{* * *} \\
(11.53)\end{array}$ & $\begin{array}{c}0.0136^{* * *} \\
(10.65)\end{array}$ & $\begin{array}{c}0.0137^{* * *} \\
(10.89)\end{array}$ \\
\hline$\triangle N P L_{i, t-1}$ & $\begin{array}{c}0.0158^{* * *} \\
(13.32)\end{array}$ & $\begin{array}{c}0.0159^{* * *} \\
(13.05)\end{array}$ & $\begin{array}{c}0.0157^{* * *} \\
(13.17)\end{array}$ & $\begin{array}{c}0.0161^{* * *} \\
(13.56)\end{array}$ & $\begin{array}{c}0.0161^{* * *} \\
(13.42)\end{array}$ & $\begin{array}{c}0.0163^{* * * *} \\
(12.28)\end{array}$ & $\begin{array}{c}0.0166^{* * *} \\
(12.79)\end{array}$ \\
\hline$\triangle N P L_{i, t}$ & $\begin{array}{c}0.0365^{* * *} \\
(16.46)\end{array}$ & $\begin{array}{c}0.0364^{* * *} \\
(16.26)\end{array}$ & $\begin{array}{c}0.0363^{* * *} \\
(16.43)\end{array}$ & $\begin{array}{c}0.0365^{* * *} \\
(16.67)\end{array}$ & $\begin{array}{c}0.0367^{* * *} \\
(16.45)\end{array}$ & $\begin{array}{c}0.0395^{* * * *} \\
(16.27)\end{array}$ & $\begin{array}{c}0.0395^{* * *} \\
(16.34)\end{array}$ \\
\hline$\triangle N P L_{i, t+1}$ & $\begin{array}{c}0.0105^{* * *} \\
(11.31)\end{array}$ & $\begin{array}{c}0.0104^{* * *} \\
(10.83)\end{array}$ & $\begin{array}{c}0.0103^{* * *} \\
(10.82)\end{array}$ & $\begin{array}{c}0.0107^{* * * *} \\
(11.08)\end{array}$ & $\begin{array}{c}0.0107^{* * *} \\
(11.34)\end{array}$ & $\begin{array}{c}0.0106^{* * *} \\
(10.10)\end{array}$ & $\begin{array}{c}0.0107^{* * *} \\
(10.47)\end{array}$ \\
\hline$S I Z E_{i, t-1}$ & $\begin{array}{l}0.0000 \\
(0.38)\end{array}$ & $\begin{array}{c}-0.0000 \\
(-1.63)\end{array}$ & $\begin{array}{c}0.0000 \\
(0.98)\end{array}$ & $\begin{array}{c}-0.0000 \\
(-1.28)\end{array}$ & $\begin{array}{c}-0.0000 \\
(-1.31)\end{array}$ & $\begin{array}{c}0.0000 \\
(0.29)\end{array}$ & $\begin{array}{c}0.0000 \\
(0.08)\end{array}$ \\
\hline$\triangle L O A N_{i, t}$ & $\begin{array}{c}0.0019^{* * *} \\
(9.58)\end{array}$ & $\begin{array}{c}0.0019^{* * *} \\
(10.12)\end{array}$ & $\begin{array}{c}0.0019^{* * *} \\
(10.24)\end{array}$ & $\begin{array}{c}0.0020^{* * *} \\
(10.70)\end{array}$ & $\begin{array}{c}0.0020^{* * * *} \\
(10.53)\end{array}$ & $\begin{array}{c}0.0012^{* * *} \\
(4.52)\end{array}$ & $\begin{array}{c}0.0014^{* * * *} \\
(5.22)\end{array}$ \\
\hline$E B P_{i, t}$ & $\begin{array}{c}-0.0085^{* *} \\
(-2.42)\end{array}$ & $\begin{array}{c}-0.0064^{*} \\
(-1.98)\end{array}$ & $\begin{array}{c}-0.0082^{* *} \\
(-2.59)\end{array}$ & $\begin{array}{c}-0.0076^{* *} \\
(-2.45)\end{array}$ & $\begin{array}{c}-0.0070^{* *} \\
(-2.08)\end{array}$ & $\begin{array}{c}-0.0135^{* * *} \\
(-3.09)\end{array}$ & $\begin{array}{c}-0.0137^{* * *} \\
(-3.13)\end{array}$ \\
\hline$C O_{i, t}$ & $\begin{array}{c}0.6885^{* * *} \\
(35.53)\end{array}$ & $\begin{array}{c}0.6864^{* * *} \\
(36.21)\end{array}$ & $\begin{array}{c}0.6862^{* * *} \\
(37.03)\end{array}$ & $\begin{array}{c}0.6842^{* * *} \\
(37.73)\end{array}$ & $\begin{array}{c}0.6857^{* * *} \\
(35.88)\end{array}$ & $\begin{array}{c}0.6935^{* * *} \\
(30.45)\end{array}$ & $\begin{array}{c}0.6913^{* * *} \\
(30.10)\end{array}$ \\
\hline$C A P R 1_{i, t-1}$ & $\begin{array}{c}0.0017^{* * *} \\
(5.84)\end{array}$ & $\begin{array}{c}0.0017^{* * *} \\
(6.05)\end{array}$ & $\begin{array}{c}0.0018^{* * *} \\
(6.33)\end{array}$ & $\begin{array}{c}0.0017^{* * * *} \\
(6.09)\end{array}$ & $\begin{array}{c}0.0016^{* * *} \\
(5.82)\end{array}$ & $\begin{array}{c}0.0020^{* * * *} \\
(4.58)\end{array}$ & $\begin{array}{c}0.0020^{* * * *} \\
(4.74)\end{array}$ \\
\hline$A L W_{i, t-1}$ & $\begin{array}{c}-0.0319^{* * *} \\
(-13.63)\end{array}$ & $\begin{array}{c}-0.0319^{* * *} \\
(-13.05)\end{array}$ & $\begin{array}{c}-0.0318^{* * *} \\
(-13.02)\end{array}$ & $\begin{array}{c}-0.0351^{* * *} \\
(-13.37)\end{array}$ & $\begin{array}{c}-0.0338^{* * *} \\
(-14.01)\end{array}$ & $\begin{array}{c}-0.0389^{* * *} \\
(-9.45)\end{array}$ & $\begin{array}{c}-0.0405^{* * *} \\
(-9.95)\end{array}$ \\
\hline EARNINGVOL $_{i, t-1}$ & $\begin{array}{c}0.0125^{* * *} \\
(19.36)\end{array}$ & $\begin{array}{c}0.0121^{* * *} \\
(19.19)\end{array}$ & $\begin{array}{c}0.0124^{* * * *} \\
(19.74)\end{array}$ & $\begin{array}{c}0.0121^{* * * *} \\
(19.31)\end{array}$ & $\begin{array}{c}0.0122^{* * *} \\
(19.29)\end{array}$ & $\begin{array}{c}0.0121^{* * * *} \\
(14.08)\end{array}$ & $\begin{array}{c}0.0117^{* * *} \\
(13.77)\end{array}$ \\
\hline HOMOGENEITY ${ }_{i, t}$ & $\begin{array}{c}-0.0004^{* * *} \\
(-3.99)\end{array}$ & $\begin{array}{c}-0.0002^{* *} \\
(-2.47)\end{array}$ & $\begin{array}{c}-0.0004^{* * *} \\
(-3.76)\end{array}$ & $\begin{array}{c}-0.0004^{* * *} \\
(-4.24)\end{array}$ & $\begin{array}{c}-0.0003^{* * *} \\
(-3.56)\end{array}$ & $\begin{array}{c}-0.0004^{* * *} \\
(-3.06)\end{array}$ & $\begin{array}{c}-0.0005^{* * *} \\
(-3.13)\end{array}$ \\
\hline PUBLIC $C_{i, t}$ & $\begin{array}{c}-0.0000 \\
(-0.01)\end{array}$ & $\begin{array}{l}-0.0000 \\
(-0.36)\end{array}$ & $\begin{array}{c}-0.0000 \\
(-0.33)\end{array}$ & $\begin{array}{c}0.0000 \\
(0.89)\end{array}$ & $\begin{array}{c}0.0000 \\
(0.59)\end{array}$ & $\begin{array}{c}0.0000 \\
(0.50)\end{array}$ & $\begin{array}{c}0.0000 \\
(0.76)\end{array}$ \\
\hline INTCONTROL $_{i, t}$ & $\begin{array}{c}0.0001^{* * *} \\
(3.34)\end{array}$ & $\begin{array}{c}0.0001^{* * *} \\
(4.22)\end{array}$ & $\begin{array}{c}0.0001^{* * *} \\
(3.41)\end{array}$ & $\begin{array}{c}0.0001^{* * *} \\
(3.87)\end{array}$ & $\begin{array}{c}0.0001^{* * *} \\
(3.94)\end{array}$ & $\begin{array}{c}0.0001^{* *} \\
(2.39)\end{array}$ & $\begin{array}{c}0.0001^{* *} \\
(2.51)\end{array}$ \\
\hline$G D P G R W_{t}$ & $0.0001^{*}$ & $0.0001^{*}$ & 0.0001 & 0.0000 & $0.0001^{* *}$ & $0.0002^{* *}$ & $0.0002^{* *}$ \\
\hline
\end{tabular}




\begin{tabular}{|c|c|c|c|c|c|c|c|}
\hline & $(1.76)$ & $(1.76)$ & (1.59) & $(0.95)$ & $(2.07)$ & $(2.02)$ & $(2.05)$ \\
\hline \multirow{2}{*}{$U N E M P G R W_{t}$} & 0.0000 & -0.0000 & 0.0001 & 0.0000 & 0.0001 & -0.0003 & -0.0000 \\
\hline & $(0.24)$ & $(-0.08)$ & $(0.51)$ & $(0.20)$ & $(0.42)$ & $(-1.38)$ & $(-0.05)$ \\
\hline \multirow{2}{*}{$\operatorname{CSRET}_{t}$} & $-0.0046^{* * *}$ & $-0.0034^{* *}$ & -0.0017 & $-0.0023^{* *}$ & $-0.0037^{* * *}$ & -0.0020 & -0.0017 \\
\hline & $(-3.14)$ & $(-2.34)$ & $(-1.03)$ & $(-2.06)$ & $(-3.01)$ & $(-1.24)$ & $(-1.28)$ \\
\hline Bank fixed effects & Yes & Yes & Yes & Yes & Yes & Yes & Yes \\
\hline Obs. & 634,059 & 634,059 & 634,059 & 634,059 & 634,059 & 41,8361 & 41,8361 \\
\hline Adjusted $R^{2}$ & 0.561 & 0.562 & 0.562 & 0.564 & 0.563 & 0.569 & 0.570 \\
\hline
\end{tabular}

This table presents the main results of regressing quarterly loan loss provisions on policy uncertainty. The dependent variable, $L L P_{i, t}$, is defined as loan loss provisions in quarter $t$ scaled by lagged total outstanding loans. The independent variable, $P U I_{\text {Index }}$, is the natural log of the quarterly average PU index in quarter t. The first four columns consider each component of Baker, Bloom and Davis' (2016) PU index and the other columns consider their overall PU index, which is the weighted average of the four components. All control variables are defined in Appendix A. Columns (6)-(7) present the results after further controlling for managerial sentiment $\left(B E L I E F S_{t}\right)$ obtained from the Duke/CFO Magazine Global Business Outlook survey. All continuous variables are winsorized at the 1st and 99th percentiles. The model includes bank fixed effects; t-values, based on robust standard errors clustered by bank and quarter, are reported in parentheses. ${ }^{* * *},{ }^{* *}$ and ${ }^{*}$ represent significance at the $1 \%, 5 \%$ and $10 \%$ levels, respectively. 
Table 3

Robustness checks

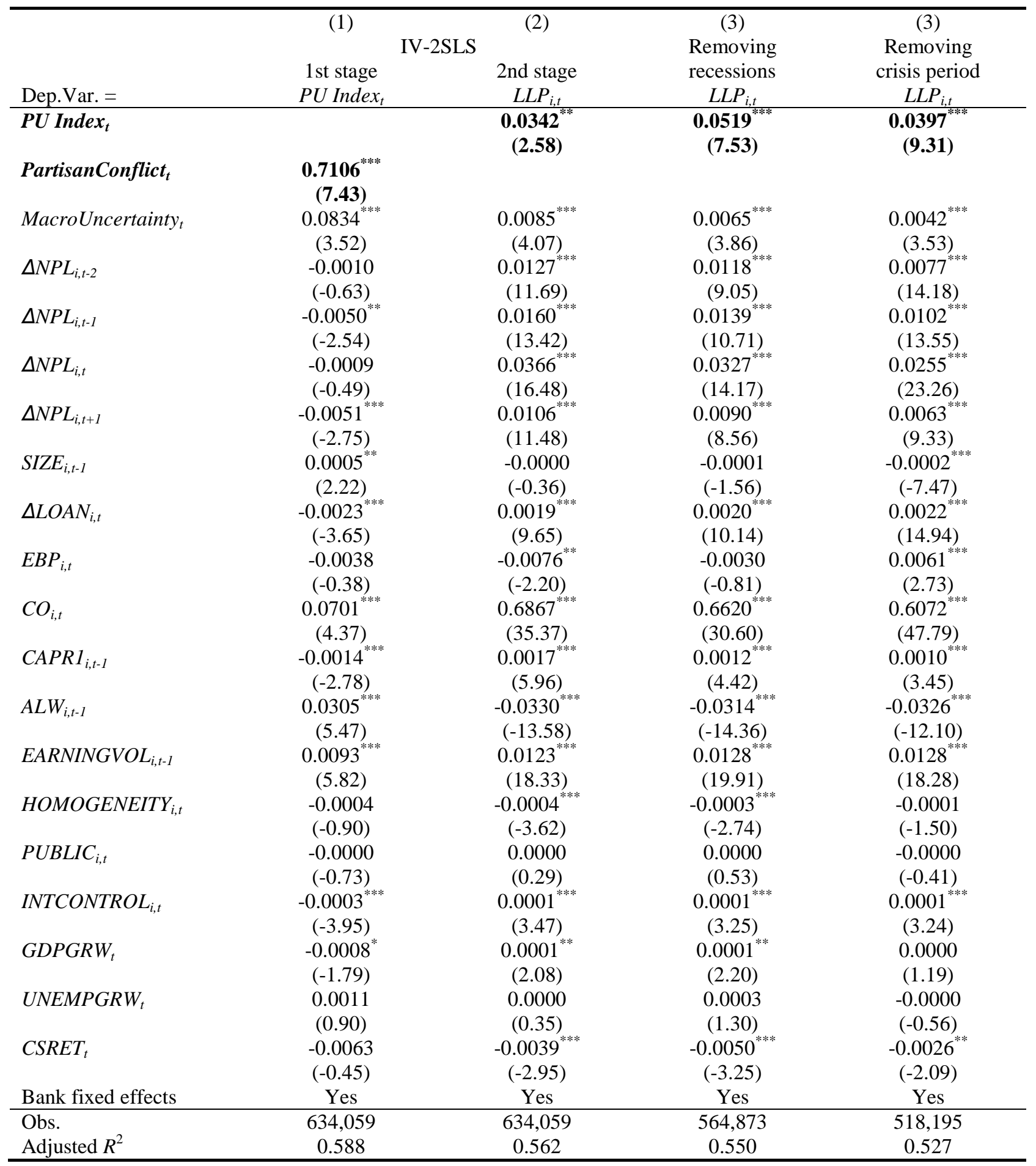

In this table, columns (1)-(2) present the results of the IV-2SLS estimation. The instrumental variable, PartisanConflict, is Azzimonti's (2016) partisan-conflict index from the Federal Reserve Bank of Philadelphia, which is based on a frequency count of newspaper articles containing terms related to lawmakers' policy disagreements. Column (3) excludes observations during recession periods, as defined by NBER, while column (4) excludes observations during the crisis period from 2007Q1 to 2010Q4. All other variables are defined in Appendix A. All continuous variables are winsorized at the 1st and 99th percentiles. The model includes bank fixed effects; tvalues, based on robust standard errors clustered by bank and quarter, are reported in parentheses. ${ }^{* * *},{ }^{* *}$ and ${ }^{*}$ represent significance at the $1 \%, 5 \%$ and $10 \%$ levels, respectively. 
Table 4

Test of H2: The role of bank risk

\begin{tabular}{|c|c|c|c|}
\hline Dep.Var. $=L L P_{i, t}$ & $\begin{array}{c}\text { Nonperforming loan } \\
N P L_{i, t-1}\end{array}$ & $\begin{array}{c}\text { Loan diversification } \\
L D I V_{i, t-1}\end{array}$ & $\begin{array}{c}\text { Capital adequacy } \\
C A P R 1_{i, t-1}\end{array}$ \\
\hline PU Index & $\begin{array}{l}0.0261^{* * *} \\
(3.86)\end{array}$ & $\begin{array}{l}0.0630^{* * *} \\
(7.56)\end{array}$ & $\begin{array}{l}0.0699^{* * *} \\
(8.53)\end{array}$ \\
\hline PU Index $\times$ $\times$ High & $\begin{array}{c}0.0494^{* * *} \\
(8.89)\end{array}$ & $\begin{array}{c}-0.0296^{* * *} \\
(-5.31)\end{array}$ & $\begin{array}{c}-0.0413^{* * *} \\
(-7.44)\end{array}$ \\
\hline High & $\begin{array}{c}-0.0020^{* * *} \\
(-8.22)\end{array}$ & $\begin{array}{l}0.0014^{* * *} \\
(5.45)\end{array}$ & $\begin{array}{c}0.0019^{* * *} \\
(7.26)\end{array}$ \\
\hline MacroUncertainty & $\begin{array}{c}0.0074^{* * *} \\
(3.35)\end{array}$ & $\begin{array}{c}0.0077^{* * *} \\
(3.52)\end{array}$ & $\begin{array}{l}0.0070^{* * *} \\
(3.26)\end{array}$ \\
\hline$\triangle N P L_{i, t-2}$ & $\begin{array}{c}0.0112^{* * *} \\
(11.10)\end{array}$ & $\begin{array}{l}0.0128^{* * *} \\
(11.63)\end{array}$ & $\begin{array}{c}0.0126^{* * *} \\
(11.53)\end{array}$ \\
\hline$\triangle N P L_{i, t-1}$ & $\begin{array}{c}0.0138^{* * *} \\
(13.33)\end{array}$ & $\begin{array}{l}0.0162^{* * *} \\
(13.60)\end{array}$ & $\begin{array}{c}0.0160^{* * *} \\
(13.57)\end{array}$ \\
\hline$\triangle N P L_{i, t}$ & $\begin{array}{c}0.0385^{* * *} \\
(17.01)\end{array}$ & $\begin{array}{c}0.0365^{* * *} \\
(16.50)\end{array}$ & $\begin{array}{c}0.0364^{* * *} \\
(16.61)\end{array}$ \\
\hline$\triangle N P L_{i, t+1}$ & $\begin{array}{l}0.0121^{* * *} \\
(12.87)\end{array}$ & $\begin{array}{c}0.0107^{* * *} \\
(11.58)\end{array}$ & $\begin{array}{l}0.0106^{* * *} \\
(11.48)\end{array}$ \\
\hline$S I Z E_{i, t-1}$ & $\begin{array}{l}-0.0000 \\
(-1.41)\end{array}$ & $\begin{array}{l}-0.0000 \\
(-1.24)\end{array}$ & $\begin{array}{c}-0.0001^{* * *} \\
(-2.71)\end{array}$ \\
\hline$\triangle L O A N_{i, t}$ & $\begin{array}{l}0.0021^{* * *} \\
(11.60)\end{array}$ & $\begin{array}{c}0.0019^{* * *} \\
(10.64)\end{array}$ & $\begin{array}{c}0.0021^{* * *} \\
(11.25)\end{array}$ \\
\hline$E B P_{i, t}$ & $\begin{array}{c}-0.0059^{*} \\
(-1.75)\end{array}$ & $\begin{array}{l}-0.0075^{* *} \\
(-2.24)\end{array}$ & $\begin{array}{l}-0.0071^{* *} \\
(-2.08)\end{array}$ \\
\hline$C O_{i, t}$ & $\begin{array}{c}0.6794^{* * *} \\
(35.90)\end{array}$ & $\begin{array}{c}0.6847^{* * *} \\
(35.72)\end{array}$ & $\begin{array}{c}0.6830^{* * *} \\
(35.83)\end{array}$ \\
\hline$C A P R 1_{i, t-1}$ & $\begin{array}{c}0.0017^{* * *} \\
(5.87)\end{array}$ & $\begin{array}{c}0.0017^{* * *} \\
(6.08)\end{array}$ & \\
\hline$A L W_{i, t-1}$ & $\begin{array}{c}-0.0374^{* * *} \\
(-14.78)\end{array}$ & $\begin{array}{c}-0.0349^{* * *} \\
(-14.30)\end{array}$ & $\begin{array}{c}-0.0334^{* * *} \\
(-13.86)\end{array}$ \\
\hline EARNINGVOL $L_{i, t-1}$ & $\begin{array}{l}0.0126^{* * *} \\
(20.07)\end{array}$ & $\begin{array}{l}0.0123^{* * *} \\
(19.48)\end{array}$ & $\begin{array}{l}0.0136^{* * *} \\
(21.96)\end{array}$ \\
\hline HOMOGENEITY ${ }_{i, t}$ & $\begin{array}{c}-0.0004^{* * *} \\
(-3.56)\end{array}$ & $\begin{array}{c}-0.0004^{* * *} \\
(-3.75)\end{array}$ & $\begin{array}{c}-0.0003^{* * *} \\
(-3.31)\end{array}$ \\
\hline$P U B L I C_{i, t}$ & $\begin{array}{l}0.0000 \\
(0.30)\end{array}$ & $\begin{array}{l}0.0000 \\
(0.40)\end{array}$ & $\begin{array}{c}0.0000 \\
(0.86)\end{array}$ \\
\hline INTCONTROL $_{i, t}$ & $\begin{array}{l}0.0001^{* * *} \\
(3.25)\end{array}$ & $\begin{array}{l}0.0001^{* * *} \\
(3.32)\end{array}$ & $\begin{array}{c}0.0001^{* * *} \\
(4.47)\end{array}$ \\
\hline$G D P G R W_{t}$ & $\begin{array}{c}0.0001^{* *} \\
(2.07)\end{array}$ & $\begin{array}{c}0.0001^{* *} \\
(2.05)\end{array}$ & $\begin{array}{c}0.0001^{*} \\
(1.97)\end{array}$ \\
\hline$U N E M P G R W_{t}$ & $\begin{array}{l}0.0001 \\
(0.41)\end{array}$ & $\begin{array}{l}0.0001 \\
(0.40)\end{array}$ & $\begin{array}{l}0.0001 \\
(0.39)\end{array}$ \\
\hline$C S R E T_{t}$ & $\begin{array}{c}-0.0038^{* * *} \\
(-3.04)\end{array}$ & $\begin{array}{c}-0.0037^{* * *} \\
(-3.00)\end{array}$ & $\begin{array}{c}-0.0038^{* * *} \\
(-3.17)\end{array}$ \\
\hline Bank fixed effects & Yes & Yes & Yes \\
\hline $\begin{array}{l}\text { Obs. } \\
\text { Adjusted } R^{2}\end{array}$ & $\begin{array}{c}634,059 \\
0.565\end{array}$ & $\begin{array}{c}630,608 \\
0.557\end{array}$ & $\begin{array}{c}634,059 \\
0.562\end{array}$ \\
\hline
\end{tabular}

This table presents the results of testing H2. In columns (1) and (2), we use two distinct measures to proxy for loan portfolio risk: Nonperforming loans $\left(N P L_{i, t-1}\right)$ measure the quality of the loan portfolio at the end of quarter $\mathrm{t}-1$, calculated as nonperforming assets divided by total outstanding loans; Loan type diversification $\left(L D I V_{i, t-1}\right)$ is calculated as one minus the Herfindahl index of the distribution of real estate loans, commercial and industrial loans; loans to depository institutions; agricultural loans; loans to individuals and loans to foreign governments. In column (3), we consider the regulatory-capital-related risk $\left(C A P R 1_{i, t-1}\right)$. To ease the interpretation of the coefficient on the interaction term, we create a dummy variable for each measurement according to its quarterly median value. The models include bank fixed effects; t-values, based on robust standard errors clustered by bank and quarter, are reported in parentheses. ${ }^{* * *},{ }^{* *}$ and ${ }^{*}$ represent significance at the $1 \%, 5 \%$ and $10 \%$ levels, respectively. 
Table 5

Test of H3: The role of prior reserves

\begin{tabular}{|c|c|c|}
\hline Dep.Var. $=L L P_{i, t}$ & $\begin{array}{l}\text { Reserves adequacy measured by } \\
\qquad A L W_{t-1} / N P L_{t-1}\end{array}$ & $\begin{array}{l}\text { Reserves adequacy measured by } \\
\qquad A L W_{t-1} / C O_{t-1}\end{array}$ \\
\hline PU Index & $\begin{array}{l}0.0619^{* * *} \\
(6.77)\end{array}$ & $\begin{array}{l}0.0563^{* * *} \\
(6.78)\end{array}$ \\
\hline PU Index $\times$ $\times$ High & $\begin{array}{c}-0.0482^{* * *} \\
(-7.13)\end{array}$ & $\begin{array}{c}-0.0381^{* * *} \\
(-8.66)\end{array}$ \\
\hline High & $\begin{array}{l}0.0019^{* * *} \\
(6.39)\end{array}$ & $\begin{array}{l}0.0016^{* * *} \\
(7.90)\end{array}$ \\
\hline MacroUncertainty $_{t}$ & $\begin{array}{l}0.0093^{* * *} \\
(3.86)\end{array}$ & $\begin{array}{l}0.0095^{* * *} \\
(3.99)\end{array}$ \\
\hline$\triangle N P L_{i, t-2}$ & $\begin{array}{c}0.0114^{* * *} \\
(12.08)\end{array}$ & $\begin{array}{c}0.0140^{* * *} \\
(12.93)\end{array}$ \\
\hline$\triangle N P L_{i, t-1}$ & $\begin{array}{l}0.0142^{* * *} \\
(15.05)\end{array}$ & $\begin{array}{l}0.0178^{* * *} \\
(15.45)\end{array}$ \\
\hline$\triangle N P L_{i, t}$ & $\begin{array}{l}0.0404^{* * *} \\
(18.15)\end{array}$ & $\begin{array}{l}0.0393^{* * *} \\
(17.83)\end{array}$ \\
\hline$\triangle N P L_{i, t+1}$ & $\begin{array}{c}0.0147^{* * *} \\
(14.38)\end{array}$ & $\begin{array}{l}0.0135^{* * *} \\
(12.61)\end{array}$ \\
\hline$S I Z E_{i, t-1}$ & $\begin{array}{c}0.0001^{*} \\
(1.82)\end{array}$ & $\begin{array}{l}0.0001 \\
(1.49)\end{array}$ \\
\hline$\triangle L O A N_{i, t}$ & $\begin{array}{l}0.0013^{* * *} \\
(8.02)\end{array}$ & $\begin{array}{l}0.0011^{* * *} \\
(6.55)\end{array}$ \\
\hline$E B P_{i, t}$ & $\begin{array}{c}0.0080^{* *} \\
(2.27)\end{array}$ & $\begin{array}{l}0.0063 \\
(1.66)\end{array}$ \\
\hline$C O_{i, t}$ & $\begin{array}{l}0.6449^{* * *} \\
(35.92)\end{array}$ & $\begin{array}{l}0.6516^{* * *} \\
(36.06)\end{array}$ \\
\hline$C A P R 1_{i, t-1}$ & $\begin{array}{l}-0.0010^{* * *} \\
(-5.28)\end{array}$ & $\begin{array}{c}-0.0010^{* * *} \\
(-5.01)\end{array}$ \\
\hline EARNINGVOL $_{i, t-1}$ & $\begin{array}{c}0.0089^{* * *} \\
(11.92)\end{array}$ & $\begin{array}{c}0.0097^{* * *} \\
(11.93)\end{array}$ \\
\hline HOMOGENEITY $_{i, t}$ & $\begin{array}{c}-0.0002^{*} \\
(-1.94)\end{array}$ & $\begin{array}{c}-0.0002^{*} \\
(-1.78)\end{array}$ \\
\hline$P U B L I C_{i, t}$ & $\begin{array}{l}0.0000 \\
(0.18)\end{array}$ & $\begin{array}{l}0.0000 \\
(0.43)\end{array}$ \\
\hline INTCONTROL $_{i, t}$ & $\begin{array}{c}-0.0000 \\
(-0.15)\end{array}$ & $\begin{array}{c}0.0000 \\
(0.93)\end{array}$ \\
\hline$G D P G R W_{t}$ & $\begin{array}{c}0.0001^{* *} \\
(2.10)\end{array}$ & $\begin{array}{c}0.0001^{* *} \\
(2.15)\end{array}$ \\
\hline$U N E M P G R W_{t}$ & $\begin{array}{l}0.0001 \\
(0.64)\end{array}$ & $\begin{array}{l}0.0001 \\
(0.64)\end{array}$ \\
\hline $\operatorname{CSRET}_{t}$ & $\begin{array}{c}-0.0042^{* * *} \\
(-3.29)\end{array}$ & $\begin{array}{c}-0.0042^{* * *} \\
(-3.35)\end{array}$ \\
\hline Bank fixed effects & Yes & Yes \\
\hline $\begin{array}{l}\text { Obs. } \\
\text { Adjusted } R^{2}\end{array}$ & $\begin{array}{c}578,924 \\
0.571\end{array}$ & $\begin{array}{c}537,535 \\
0.576\end{array}$ \\
\hline
\end{tabular}

This table presents the results of testing H3. The adequacy of the loan loss reserves is defined as the prior quarter loan loss allowance $\left(A L W_{t-1}\right)$ scaled by nonperforming loans $\left(N P L_{t-1}\right)$ or net charge-offs $\left(C O_{t-1}\right)$. To ease the interpretation of the coefficient on the interaction term, we create a dummy variable for each measurement. The dummy variable (High) is coded as 1 if the corresponding value is greater than its quarterly median, 0 otherwise. All other variables are defined in Appendix A. All continuous variables are winsorized at the 1st and 99th percentiles. The models include bank fixed effects; t-values, based on robust standard errors clustered by bank and quarter, are reported in parentheses. ${ }^{* * *},{ }^{* *}$ and ${ }^{*}$ represent significance at the $1 \%, 5 \%$ and $10 \%$ levels, respectively. 
Table 6

Test of H4: The impact of PU on future charge-offs and the moderating effect of loan loss provisions

\begin{tabular}{|c|c|c|c|c|}
\hline \multirow[t]{2}{*}{ Dep.Var. = } & \multicolumn{2}{|c|}{$C O_{i, t+1}$} & \multicolumn{2}{|c|}{$C O_{i, t+1234}$} \\
\hline & $\begin{array}{c}\text { Without } \\
\text { interaction }\end{array}$ & $\begin{array}{c}\text { Interact with } \\
\text { High } L L P_{i, t}\end{array}$ & $\begin{array}{l}\text { Without } \\
\text { interaction }\end{array}$ & $\begin{array}{l}\text { Interact with } \\
\text { High } L L P_{i, t}\end{array}$ \\
\hline$P U$ Index $_{t}$ & $\begin{array}{c}0.0437^{* * *} \\
(2.85)\end{array}$ & $\begin{array}{l}0.0103 \\
(0.86)\end{array}$ & $\begin{array}{c}0.0833^{* * *} \\
(2.68)\end{array}$ & $\begin{array}{l}-0.0336 \\
(-1.13)\end{array}$ \\
\hline PU Index $\times$ $\times$ High & & $\begin{array}{c}0.07288^{* * *} \\
(5.84)\end{array}$ & & $\begin{array}{c}0.2548^{* * *} \\
(6.49)\end{array}$ \\
\hline High & & $\begin{array}{c}-0.0029^{* * *} \\
(-5.07)\end{array}$ & & $\begin{array}{c}-0.0102^{* * *} \\
(-5.72)\end{array}$ \\
\hline MacroUncertainty $_{t}$ & $\begin{array}{c}0.0030 \\
(0.78)\end{array}$ & $\begin{array}{l}0.0030 \\
(0.78)\end{array}$ & $\begin{array}{c}0.0344^{* * *} \\
(4.59)\end{array}$ & $\begin{array}{c}0.0343^{* * *} \\
(4.56)\end{array}$ \\
\hline$\triangle N P L_{i, t-2}$ & $\begin{array}{c}0.0217^{* * *} \\
(10.10)\end{array}$ & $\begin{array}{c}0.0207^{* * *} \\
(10.00)\end{array}$ & $\begin{array}{c}0.0795^{* * *} \\
(12.27)\end{array}$ & $\begin{array}{c}0.0764^{* * *} \\
(12.34)\end{array}$ \\
\hline$\triangle N P L_{i, t-1}$ & $\begin{array}{c}0.0238^{* * *} \\
(10.71)\end{array}$ & $\begin{array}{c}0.0228^{* * *} \\
(10.72)\end{array}$ & $\begin{array}{c}0.0985^{* * *} \\
(13.44)\end{array}$ & $\begin{array}{c}0.0951^{* * *} \\
(13.71)\end{array}$ \\
\hline$\triangle N P L_{i, t}$ & $\begin{array}{c}0.0339^{* * *} \\
(12.71)\end{array}$ & $\begin{array}{c}0.0321^{* * *} \\
(12.78)\end{array}$ & $\begin{array}{c}0.1467^{* * *} \\
(16.46)\end{array}$ & $\begin{array}{c}0.1406^{* * *} \\
(16.96)\end{array}$ \\
\hline$\Delta N P L_{i, t+1}$ & $\begin{array}{c}-0.0197^{* * *} \\
(-12.22)\end{array}$ & $\begin{array}{c}-0.0201^{* * *} \\
(-12.92)\end{array}$ & $\begin{array}{c}0.0824^{* * *} \\
(10.72)\end{array}$ & $\begin{array}{c}0.0811^{* * *} \\
(10.93)\end{array}$ \\
\hline$S I Z E_{i, t-1}$ & $\begin{array}{c}0.0002^{* *} \\
(2.50)\end{array}$ & $\begin{array}{c}0.0001^{* *} \\
(2.21)\end{array}$ & $\begin{array}{c}0.0009^{* * *} \\
(5.01)\end{array}$ & $\begin{array}{c}0.0008^{* * *} \\
(4.63)\end{array}$ \\
\hline$\triangle L O A N_{i, t}$ & $\begin{array}{c}-0.0023^{* * *} \\
(-12.08)\end{array}$ & $\begin{array}{c}-0.0025^{* * *} \\
(-13.12)\end{array}$ & $\begin{array}{c}-0.0074^{* * *} \\
(-12.45)\end{array}$ & $\begin{array}{c}-0.0082^{* * *} \\
(-13.47)\end{array}$ \\
\hline$E B P_{i, t}$ & $\begin{array}{c}-0.0055 \\
(-1.53)\end{array}$ & $\begin{array}{c}-0.0077^{* *} \\
(-2.17)\end{array}$ & $\begin{array}{c}-0.0514^{* * *} \\
(-4.75)\end{array}$ & $\begin{array}{c}-0.0588^{* * *} \\
(-5.44)\end{array}$ \\
\hline$C O_{i, t}$ & $\begin{array}{c}0.1411^{* * *} \\
(11.27)\end{array}$ & $\begin{array}{c}0.1079^{* * * *} \\
(8.89)\end{array}$ & $\begin{array}{c}0.5818^{* * *} \\
(24.00)\end{array}$ & $\begin{array}{l}0.4728^{* * *} \\
(20.11)\end{array}$ \\
\hline$C A P R 1_{i, t-1}$ & $\begin{array}{c}-0.0025^{* * *} \\
(-10.41)\end{array}$ & $\begin{array}{c}-0.0024^{* * *} \\
(-9.87)\end{array}$ & $\begin{array}{c}-0.0071^{* * *} \\
(-8.58)\end{array}$ & $\begin{array}{c}-0.0067^{* * *} \\
(-8.20)\end{array}$ \\
\hline$A L W_{i, t-1}$ & $\begin{array}{c}0.0748^{* * *} \\
(18.18)\end{array}$ & $\begin{array}{c}0.0786^{* * * *} \\
(19.22)\end{array}$ & $\begin{array}{c}0.2137^{* * *} \\
(17.16)\end{array}$ & $\begin{array}{c}0.2253^{* * *} \\
(18.37)\end{array}$ \\
\hline EARNINGVOL $_{i, t-1}$ & $\begin{array}{c}0.0024^{* * *} \\
(4.12)\end{array}$ & $\begin{array}{c}0.0012^{* *} \\
(2.05)\end{array}$ & $\begin{array}{c}0.0068^{* * *} \\
(2.72)\end{array}$ & $\begin{array}{l}0.0031 \\
(1.24)\end{array}$ \\
\hline HOMOGENEITY $Y_{i, t}$ & $\begin{array}{c}0.0006^{* * *} \\
(4.16)\end{array}$ & $\begin{array}{c}0.0006^{* * *} \\
(4.61)\end{array}$ & $\begin{array}{c}0.0008^{*} \\
(1.94)\end{array}$ & $\begin{array}{c}0.0010^{* *} \\
(2.40)\end{array}$ \\
\hline PUBLIC $C_{i, t}$ & $\begin{array}{c}-0.0000 \\
(-0.47)\end{array}$ & $\begin{array}{l}-0.0000 \\
(-0.43)\end{array}$ & $\begin{array}{c}0.0003^{* *} \\
(2.06)\end{array}$ & $\begin{array}{c}0.0003^{* *} \\
(2.17)\end{array}$ \\
\hline $\operatorname{INTCONTROL}_{i, t}$ & $\begin{array}{c}0.0001^{* * *} \\
(3.80)\end{array}$ & $\begin{array}{c}0.0001^{* * *} \\
(3.54)\end{array}$ & $\begin{array}{c}0.0004^{* * *} \\
(3.15)\end{array}$ & $\begin{array}{c}0.0003^{* * *} \\
(2.79)\end{array}$ \\
\hline$G D P G R W_{t}$ & $\begin{array}{l}0.0001^{*} \\
(1.68)\end{array}$ & $\begin{array}{c}0.0001^{*} \\
(1.73)\end{array}$ & $\begin{array}{c}0.0003^{*} \\
(1.72)\end{array}$ & $\begin{array}{c}0.0003^{*} \\
(1.74)\end{array}$ \\
\hline$U N E M P G R W_{t}$ & $\begin{array}{c}0.0004^{*} \\
(1.82)\end{array}$ & $\begin{array}{c}0.0004^{*} \\
(1.92)\end{array}$ & $\begin{array}{c}0.0010^{*} \\
(1.84)\end{array}$ & $\begin{array}{c}0.0010^{*} \\
(1.94)\end{array}$ \\
\hline CSRET $_{t}$ & $\begin{array}{c}-0.0085^{* * *} \\
(-3.21)\end{array}$ & $\begin{array}{c}-0.0091^{* * *} \\
(-3.39)\end{array}$ & $\begin{array}{c}-0.0443^{* * *} \\
(-7.44)\end{array}$ & $\begin{array}{c}-0.0462^{* * *} \\
(-7.67)\end{array}$ \\
\hline Bank fixed effects & Yes & Yes & Yes & Yes \\
\hline $\begin{array}{l}\text { Obs. } \\
\text { Adjusted } R^{2}\end{array}$ & $\begin{array}{c}628,320 \\
0.311\end{array}$ & $\begin{array}{c}628,320 \\
0.320\end{array}$ & $\begin{array}{c}590,321 \\
0.477\end{array}$ & $\begin{array}{c}590,321 \\
0.488\end{array}$ \\
\hline
\end{tabular}

This table presents the results of testing H4. The dependent variables are net charge-offs, i.e., realized loan losses, in the following 1 and 4 quarters. The dummy variable (High) is coded as 1 if the loan loss provisions $\left(L L P_{i, t}\right)$ in quarter $t$ are greater than the quarterly median, 0 otherwise. All other variables are defined in Appendix A. All continuous variables are winsorized at the 1st and 99th percentiles. The models include bank fixed effects; t-values, based on robust standard errors clustered by bank and quarter, are reported in parentheses. ${ }^{* * *},{ }^{* *}$ and * represent significance at the $1 \%, 5 \%$ and $10 \%$ levels, respectively. 
Table 7

Test of H5: The effect of PU on future liquidity creation and the moderating effect of loan loss provisions

\begin{tabular}{|c|c|c|c|c|c|c|}
\hline \multirow[t]{2}{*}{ Dep.Var. = } & \multicolumn{2}{|c|}{$\triangle L O A N_{i, t+1}$} & \multicolumn{2}{|c|}{ TotalL $C_{i, t+1}$} & \multicolumn{2}{|c|}{ OffBSLC $C_{i, t+1}$} \\
\hline & $\begin{array}{c}\text { Without } \\
\text { interaction }\end{array}$ & $\begin{array}{c}\text { Interact } \\
\text { with High } \\
L L P_{i, t}\end{array}$ & $\begin{array}{c}\text { Without } \\
\text { interaction }\end{array}$ & $\begin{array}{c}\text { Interact } \\
\text { with High } \\
L L P_{i, t}\end{array}$ & $\begin{array}{c}\text { Without } \\
\text { interaction }\end{array}$ & $\begin{array}{c}\text { Interact } \\
\text { with High } \\
L L P_{i, t}\end{array}$ \\
\hline$P U$ Index $_{t}$ & $\begin{array}{c}-1.6045^{* * *} \\
(-3.99)\end{array}$ & $\begin{array}{c}-1.3385^{* * *} \\
(-2.94)\end{array}$ & $\begin{array}{c}-0.7945 \\
(-1.58)\end{array}$ & $\begin{array}{c}-0.5065 \\
(-0.99)\end{array}$ & $\begin{array}{c}-0.9171^{* * *} \\
(-6.44)\end{array}$ & $\begin{array}{c}-0.5953^{* * *} \\
(-4.33)\end{array}$ \\
\hline PU Index $\times$ $\times$ High & & $\begin{array}{c}-0.5633^{* * *} \\
(-2.90)\end{array}$ & & $\begin{array}{c}-0.5534^{* *} \\
(-1.98)\end{array}$ & & $\begin{array}{c}-0.6550 \\
(-9.19)\end{array}$ \\
\hline High & & $\begin{array}{c}0.0270^{* * *} \\
(3.05)\end{array}$ & & $\begin{array}{c}0.0327^{* *} \\
(2.55)\end{array}$ & & $\begin{array}{c}0.0310^{* * *} \\
(9.43)\end{array}$ \\
\hline MacroUncertainty $_{t}$ & $\begin{array}{c}-0.1243 \\
(-1.03)\end{array}$ & $\begin{array}{c}-0.1215 \\
(-1.01)\end{array}$ & $\begin{array}{c}-0.9074^{* * *} \\
(-5.07)\end{array}$ & $\begin{array}{c}-0.9021^{* * *} \\
(-5.04)\end{array}$ & $\begin{array}{c}-0.0858^{* *} \\
(-2.32)\end{array}$ & $\begin{array}{c}-0.0830 \\
(-2.25)\end{array}$ \\
\hline$\Delta N P L_{i, t-2}$ & $\begin{array}{c}-0.2030^{* * *} \\
(-8.41)\end{array}$ & $\begin{array}{c}-0.2033^{* * *} \\
(-8.47)\end{array}$ & $\begin{array}{c}-0.0501 \\
(-1.51)\end{array}$ & $\begin{array}{c}-0.0601^{*} \\
(-1.83)\end{array}$ & $\begin{array}{c}-0.0224^{*} \\
(-1.76)\end{array}$ & $\begin{array}{c}-0.0220^{*} \\
(-1.77)\end{array}$ \\
\hline$\Delta N P L_{i, t-1}$ & $\begin{array}{c}-0.1285^{* * *} \\
(-4.96)\end{array}$ & $\begin{array}{c}-0.1289^{* * *} \\
(-5.01)\end{array}$ & $\begin{array}{c}0.0430 \\
(1.25)\end{array}$ & $\begin{array}{c}0.0314 \\
(0.93)\end{array}$ & $\begin{array}{r}-0.0240^{*} \\
(-1.84)\end{array}$ & $\begin{array}{c}-0.0235^{*} \\
(-1.86)\end{array}$ \\
\hline$\triangle N P L_{i, t}$ & $\begin{array}{c}-0.1115^{* * *} \\
(-3.55)\end{array}$ & $\begin{array}{c}-0.1113^{* * *} \\
(-3.63)\end{array}$ & $\begin{array}{c}0.0029 \\
(0.07)\end{array}$ & $\begin{array}{c}-0.0163 \\
(-0.42)\end{array}$ & $\begin{array}{c}-0.0598^{* * *} \\
(-4.05)\end{array}$ & $\begin{array}{c}-0.0580^{* * *} \\
(-4.16)\end{array}$ \\
\hline$\triangle N P L_{i, t+1}$ & $\begin{array}{c}0.3758^{* * *} \\
(12.42)\end{array}$ & $\begin{array}{c}0.3765^{* * *} \\
(12.53)\end{array}$ & $\begin{array}{c}0.0604^{*} \\
(1.70)\end{array}$ & $\begin{array}{c}0.0585 \\
(1.66)\end{array}$ & $\begin{array}{c}-0.0121 \\
(-0.96)\end{array}$ & $\begin{array}{c}-0.0109 \\
(-0.89)\end{array}$ \\
\hline$S I Z E_{i, t-1}$ & $\begin{array}{c}-0.0164^{* * *} \\
(-8.68)\end{array}$ & $\begin{array}{c}-0.0163^{* * *} \\
(-8.64)\end{array}$ & $\begin{array}{c}0.0389^{* * *} \\
(10.46)\end{array}$ & $\begin{array}{c}0.0389^{* * *} \\
(10.54)\end{array}$ & $\begin{array}{c}0.0033^{* * *} \\
(3.78)\end{array}$ & $\begin{array}{c}0.0034^{* * *} \\
(3.91)\end{array}$ \\
\hline$E B P_{i, t}$ & $\begin{array}{c}-0.0218 \\
(-0.26)\end{array}$ & $\begin{array}{c}-0.0246 \\
(-0.29)\end{array}$ & $\begin{array}{c}-1.4778^{* * *} \\
(-7.57)\end{array}$ & $\begin{array}{c}-1.5146^{* * *} \\
(-7.72)\end{array}$ & $\begin{array}{c}0.0898^{*} \\
(1.89)\end{array}$ & $\begin{array}{c}0.0878^{*} \\
(1.87)\end{array}$ \\
\hline$C O_{i, t}$ & $\begin{array}{c}-2.4348^{* * *} \\
(-22.47)\end{array}$ & $\begin{array}{c}-2.4490^{* * *} \\
(-21.22)\end{array}$ & $\begin{array}{c}-1.0800^{* * * *} \\
(-5.67)\end{array}$ & $\begin{array}{c}-1.4363^{* * * *} \\
(-7.04)\end{array}$ & $\begin{array}{c}-0.5491^{* * *} \\
(-9.89)\end{array}$ & $\begin{array}{c}-0.5400^{* * *} \\
(-9.92)\end{array}$ \\
\hline$C A P R 1_{i, t-1}$ & $\begin{array}{c}0.1323^{* * *} \\
(13.73)\end{array}$ & $\begin{array}{c}0.1329^{* * *} \\
(13.82)\end{array}$ & $\begin{array}{c}-0.6314^{* * *} \\
(-41.08)\end{array}$ & $\begin{array}{c}-0.6291^{* * *} \\
(-41.49)\end{array}$ & $\begin{array}{c}-0.0232^{* * *} \\
(-5.37)\end{array}$ & $\begin{array}{c}-0.0227^{* * *} \\
(-5.34)\end{array}$ \\
\hline$A L W_{i, t-1}$ & $\begin{array}{c}-0.7636^{* * *} \\
(-12.65)\end{array}$ & $\begin{array}{c}-0.7436 \\
(-12.38)\end{array}$ & $\begin{array}{c}-2.5865^{* * *} \\
(-28.26)\end{array}$ & $\begin{array}{c}-2.4970^{* * * *} \\
(-27.35)\end{array}$ & $\begin{array}{c}-0.6019^{* * *} \\
(-18.75)\end{array}$ & $\begin{array}{c}-0.5828^{* * *} \\
(-17.88)\end{array}$ \\
\hline EARNINGVOL $_{i, t-1}$ & $\begin{array}{c}0.5870^{* * *} \\
(25.13)\end{array}$ & $\begin{array}{c}0.5835^{* * *} \\
(24.97)\end{array}$ & $\begin{array}{c}0.1856^{* * *} \\
(4.54)\end{array}$ & $\begin{array}{c}0.1625^{* * *} \\
(4.00)\end{array}$ & $\begin{array}{c}0.1083^{* * *} \\
(8.40)\end{array}$ & $\begin{array}{c}0.1055^{* * *} \\
(8.24)\end{array}$ \\
\hline HOMOGENEITY $_{i, t}$ & $\begin{array}{c}-0.0084^{* *} \\
(-2.43)\end{array}$ & $\begin{array}{c}-0.0083^{* *} \\
(-2.40)\end{array}$ & $\begin{array}{c}-0.3696^{* * *} \\
(-43.36)\end{array}$ & $\begin{array}{c}-0.3690^{* * *} \\
(-43.36)\end{array}$ & $\begin{array}{c}-0.0460^{* * *} \\
(-17.84)\end{array}$ & $\begin{array}{c}-0.0459^{* * *} \\
(-17.94)\end{array}$ \\
\hline PUBLIC $C_{i, t}$ & $\begin{array}{c}0.0029^{* * *} \\
(2.71)\end{array}$ & $\begin{array}{c}0.0030^{* * * *} \\
(2.76)\end{array}$ & $\begin{array}{c}-0.0033 \\
(-1.09)\end{array}$ & $\begin{array}{c}-0.0031 \\
(-1.03)\end{array}$ & $\begin{array}{l}0.0014 \\
(1.65)\end{array}$ & $\begin{array}{c}0.0015^{*} \\
(1.73)\end{array}$ \\
\hline $\operatorname{INTCONTROL}_{i, t}$ & $\begin{array}{c}0.0013 \\
(1.07)\end{array}$ & $\begin{array}{c}0.0014 \\
(1.20)\end{array}$ & $\begin{array}{c}-0.0014 \\
(-0.53)\end{array}$ & $\begin{array}{c}-0.0012 \\
(-0.46)\end{array}$ & $\begin{array}{c}-0.0004 \\
(-0.58)\end{array}$ & $\begin{array}{c}-0.0002 \\
(-0.32)\end{array}$ \\
\hline$G D P G R W_{t}$ & $\begin{array}{c}-0.0038^{*} \\
(-1.96)\end{array}$ & $\begin{array}{c}-0.0038^{*} \\
(-1.96)\end{array}$ & $\begin{array}{c}-0.0108^{* * *} \\
(-3.44)\end{array}$ & $\begin{array}{c}-0.0107^{* * *} \\
(-3.42)\end{array}$ & $\begin{array}{c}-0.0023^{* * *} \\
(-3.04)\end{array}$ & $\begin{array}{c}-0.0023^{* * *} \\
(-3.03)\end{array}$ \\
\hline$U N E M P G R W_{t}$ & $\begin{array}{c}0.0013 \\
(0.25)\end{array}$ & $\begin{array}{c}0.0014 \\
(0.25)\end{array}$ & $\begin{array}{l}0.0097 \\
(1.16)\end{array}$ & $\begin{array}{c}0.0100 \\
(1.20)\end{array}$ & $\begin{array}{l}0.0021 \\
(1.21)\end{array}$ & $\begin{array}{l}0.0021 \\
(1.22)\end{array}$ \\
\hline $\operatorname{CSRET}_{t}$ & $\begin{array}{l}0.0982 \\
(1.59)\end{array}$ & $\begin{array}{c}0.0984 \\
(1.60)\end{array}$ & $\begin{array}{c}0.2532^{* * *} \\
(2.87)\end{array}$ & $\begin{array}{c}0.2480^{* * *} \\
(2.81)\end{array}$ & $\begin{array}{c}0.0454 \\
(1.61)\end{array}$ & $\begin{array}{c}0.0460 \\
(1.63)\end{array}$ \\
\hline Bank fixed effects & Yes & Yes & Yes & Yes & Yes & Yes \\
\hline $\begin{array}{l}\text { Obs. } \\
\text { Adjusted } R^{2}\end{array}$ & $\begin{array}{c}628,223 \\
0.186\end{array}$ & $\begin{array}{c}628,223 \\
0.187\end{array}$ & $\begin{array}{c}551,346 \\
0.855\end{array}$ & $\begin{array}{c}551,346 \\
0.855\end{array}$ & $\begin{array}{c}551,346 \\
0.757\end{array}$ & $\begin{array}{c}551,346 \\
0.758\end{array}$ \\
\hline
\end{tabular}

This table presents the results of testing $\mathrm{H} 5$. The dependent variables are the change in outstanding loans from quarter $\mathrm{t}$ to quarter $\mathrm{t}+1\left(\triangle L O A N_{i, t+1}\right)$ and the liquidity creation measures introduced in Berger and Bouwman (2009), including total liquidity creation (TotalL $\left.C_{i, t+1}\right)$ and the proportion from off-balance-sheet activities $\left(O f f B S L C_{i, t+1}\right)$. The dummy variable (High) is coded as 1 if the loan loss provisions $\left(L L P_{i, t}\right)$ in quarter $t$ are greater than the quarterly median, 0 otherwise. All other variables are defined in Appendix A. All continuous variables are winsorized at the 1st and 99th percentiles. The models include bank fixed effects; t-values, based on robust standard errors clustered by bank and quarter, are reported in parentheses. ${ }^{* * *},{ }^{* *}$ and ${ }^{*}$ represent significance at the $1 \%, 5 \%$ and $10 \%$ levels, respectively. 
Table 8

Additional analysis: The effect of policy uncertainty due to regulatory, fiscal and monetary policy

\begin{tabular}{|c|c|c|c|}
\hline Dep.Var. = & $\begin{array}{c}(1) \\
L L P_{i, t}\end{array}$ & $\begin{array}{c}(2) \\
L L P_{i, t}\end{array}$ & $\begin{array}{c}(3) \\
L L P_{i, t}\end{array}$ \\
\hline Regulatory $P U_{t}$ & $\begin{array}{c}0.0305^{* * *} \\
(5.88)\end{array}$ & & \\
\hline Fiscal PU & & $\begin{array}{c}0.0203^{* * *} \\
(5.31)\end{array}$ & \\
\hline Monetary $P U_{t}$ & & & $\begin{array}{l}0.0032 \\
(0.63)\end{array}$ \\
\hline MacroUncertainty $_{t}$ & $\begin{array}{c}0.0078^{* * *} \\
(3.68)\end{array}$ & $\begin{array}{c}0.0094^{* * *} \\
(5.00)\end{array}$ & $\begin{array}{c}0.0102^{* * *} \\
(4.32)\end{array}$ \\
\hline$\Delta N P L_{i, t-2}$ & $\begin{array}{c}0.0127^{* * *} \\
(11.29)\end{array}$ & $\begin{array}{c}0.0127^{* * *} \\
(11.23)\end{array}$ & $\begin{array}{c}0.0124^{* * *} \\
(11.08)\end{array}$ \\
\hline$\Delta N P L_{i, t-1}$ & $\begin{array}{c}0.0161^{* * *} \\
(13.29)\end{array}$ & $\begin{array}{c}0.0160^{* * *} \\
(13.31)\end{array}$ & $\begin{array}{c}0.0156^{* * *} \\
(13.02)\end{array}$ \\
\hline$\triangle N P L_{i, t}$ & $\begin{array}{c}0.0366^{* * *} \\
(16.35)\end{array}$ & $\begin{array}{c}0.0365^{* * *} \\
(16.25)\end{array}$ & $\begin{array}{c}0.0364^{* * *} \\
(16.34)\end{array}$ \\
\hline$\triangle N P L_{i, t+1}$ & $\begin{array}{c}0.0106^{* * *} \\
(11.06)\end{array}$ & $\begin{array}{c}0.0106^{* * *} \\
(11.08)\end{array}$ & $\begin{array}{c}0.0103^{* * *} \\
(10.88)\end{array}$ \\
\hline$S I Z E_{i, t-1}$ & $\begin{array}{c}-0.0000 \\
(-0.78)\end{array}$ & $\begin{array}{l}0.0000 \\
(0.32)\end{array}$ & $\begin{array}{l}0.0001 \\
(1.44)\end{array}$ \\
\hline$\triangle L O A N_{i, t}$ & $\begin{array}{c}0.0020^{* * *} \\
(10.38)\end{array}$ & $\begin{array}{c}0.0020^{* * *} \\
(10.51)\end{array}$ & $\begin{array}{c}0.0019^{* * *} \\
(9.44)\end{array}$ \\
\hline$E B P_{i, t}$ & $\begin{array}{c}-0.0074^{* *} \\
(-2.27)\end{array}$ & $\begin{array}{c}-0.0083^{* *} \\
(-2.46)\end{array}$ & $\begin{array}{c}-0.0093^{* * *} \\
(-2.74)\end{array}$ \\
\hline$C O_{i, t}$ & $\begin{array}{c}0.6857^{* * *} \\
(36.44)\end{array}$ & $\begin{array}{c}0.6864^{* * *} \\
(35.70)\end{array}$ & $\begin{array}{c}0.6890^{* * *} \\
(35.79)\end{array}$ \\
\hline$C A P R 1_{i, t-1}$ & $\begin{array}{c}0.0017^{* * *} \\
(5.91)\end{array}$ & $\begin{array}{c}0.0017^{* * *} \\
(6.15)\end{array}$ & $\begin{array}{c}0.0017^{* * *} \\
(6.13)\end{array}$ \\
\hline$A L W_{i, t-1}$ & $\begin{array}{c}-0.0336^{* * *} \\
(-13.47)\end{array}$ & $\begin{array}{c}-0.0333^{* * *} \\
(-13.79)\end{array}$ & $\begin{array}{c}-0.0309^{* * *} \\
(-12.85)\end{array}$ \\
\hline EARNINGVOL $_{i, t-1}$ & $\begin{array}{c}0.0123^{* * * *} \\
(19.27)\end{array}$ & $\begin{array}{c}0.0122^{* * *} \\
(19.35)\end{array}$ & $\begin{array}{c}0.0126^{* * *} \\
(19.54)\end{array}$ \\
\hline HOMOGENEITY $_{i, t}$ & $\begin{array}{c}-0.0004^{* * *} \\
(-3.92)\end{array}$ & $\begin{array}{c}-0.0004^{* * *} \\
(-4.10)\end{array}$ & $\begin{array}{c}-0.0004^{* * * *} \\
(-4.20)\end{array}$ \\
\hline$P U B L I C_{i, t}$ & $\begin{array}{c}0.0000 \\
(0.63)\end{array}$ & $\begin{array}{c}0.0000 \\
(0.25)\end{array}$ & $\begin{array}{c}-0.0000 \\
(-0.49)\end{array}$ \\
\hline INTCONTROL $_{i, t}$ & $\begin{array}{c}0.0001^{* * *} \\
(3.70)\end{array}$ & $\begin{array}{c}0.0001^{* * *} \\
(3.58)\end{array}$ & $\begin{array}{c}0.0001^{* * *} \\
(3.08)\end{array}$ \\
\hline$G D P G R W_{t}$ & $\begin{array}{c}0.0001^{* *} \\
(2.08)\end{array}$ & $\begin{array}{c}0.0001^{* *} \\
(2.04)\end{array}$ & $\begin{array}{l}0.0001 \\
(1.38)\end{array}$ \\
\hline$U N E M P G R W_{t}$ & $\begin{array}{l}0.0001 \\
(0.62)\end{array}$ & $\begin{array}{c}-0.0000 \\
(-0.04)\end{array}$ & $\begin{array}{l}0.0000 \\
(0.12)\end{array}$ \\
\hline CSRET $_{t}$ & $\begin{array}{c}-0.0025^{* *} \\
(-2.16)\end{array}$ & $\begin{array}{c}-0.0047^{* * *} \\
(-3.61)\end{array}$ & $\begin{array}{c}-0.0044^{* * *} \\
(-2.73)\end{array}$ \\
\hline Bank fixed effects & Yes & Yes & Yes \\
\hline $\begin{array}{l}\text { Obs. } \\
\text { Adjusted } R^{2}\end{array}$ & $\begin{array}{c}634,059 \\
0.563\end{array}$ & $\begin{array}{c}634,059 \\
0.562\end{array}$ & $\begin{array}{c}634,059 \\
0.561\end{array}$ \\
\hline
\end{tabular}

This table presents the additional analysis of regressing quarterly loan loss provisions on specific types of policy uncertainty. The dependent variable, $L L P_{i, t}$, is defined as loan loss provisions in quarter $\mathrm{t}$ scaled by lagged total outstanding loans. The variables of interest are the natural log of regulatory, fiscal and monetary PU index in quarter t. All control variables are defined in Appendix A. All continuous variables are winsorized at the 1st and 99th percentiles. The model includes bank fixed effects; t-values, based on robust standard errors clustered by bank and quarter, are reported in parentheses. ${ }^{* * *},{ }^{* *}$ and ${ }^{*}$ represent significance at the $1 \%, 5 \%$ and $10 \%$ levels, respectively. 